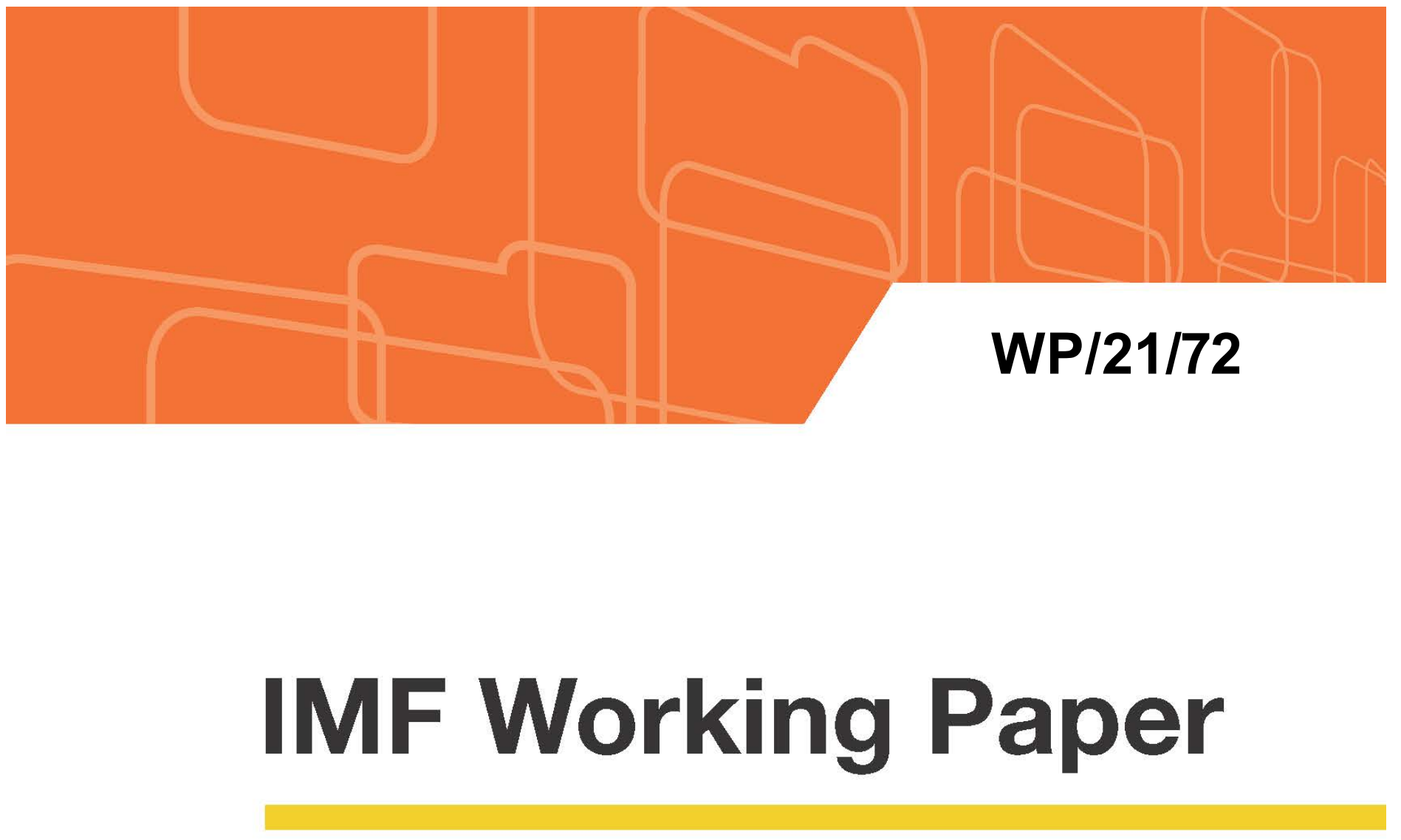

\title{
Generational Aspects of Inclusive Growth
}

by Benedicte Baduel, Asel Isakova, and Anna Ter-Martirosyan

IMF Working Papers describe research in progress by the author(s) and are published to elicit comments and to encourage debate. The views expressed in IMF Working Papers are those of the author(s) and do not necessarily represent the views of the IMF, its Executive Board, or IMF management.

I N T E R N A T I O N A L M O N E T A R Y F U N D 


\title{
IMF Working Paper
}

\author{
Institute for Capacity Development
}

\section{Generational Aspects of Inclusive Growth}

\section{Prepared by Benedicte Baduel, Asel Isakova, and Anna Ter-Martirosyan'1}

Authorized for distribution by Valerie Cerra

March 2021

IMF Working Papers describe research in progress by the author(s) and are published to elicit comments and to encourage debate. The views expressed in IMF Working Papers are those of the author(s) and do not necessarily represent the views of the IMF, its Executive Board, or IMF management.

\begin{abstract}
Sharing economic benefits equitably across all segments of society includes addressing the specific challenges of different generations. At present, youth and elderly are particularly vulnerable to poverty relative to adults in their middle years. Broad-based policies should aim to foster youth integration into the labor market and ensure adequate income and health care support for the elderly. Turning to the intergenerational dimension, everyone should have the same chances in life, regardless of their family background. Policies that promote social mobility include improving access to high-quality care and education starting from a very early age, supporting lifelong learning, effective social protection schemes, and investing in infrastructure and other services to reduce spatial segregation.
\end{abstract}

JEL Classification Numbers: D63, I24, I30, J14, J26, J62

Keywords: inequality, inclusive growth, youth employment, elderly poverty, intergenerational mobility

Authors' E-Mail Addresses: BBaduel@,imf.org; AIsakova@,imf.org; ATerMartirosyan@imf.org;

\footnotetext{
${ }^{1}$ We thank Jaime Sarmiento Monroy and Amine Yaaqoubi for the excellent research assistance. We a lso thank Boele Bonthuis, Va lerie Cerra, Barry Eichengreen, Asmaa El-Ganainy, Martin Schindler, and Nikola Spatafora, as well as participants in the Inclusive Growth book seminar series organized by theIMF Institute for Capacity Development for their comments. This is a draft of a chapter that has been accepted for publication by Oxford University Press in the forthcoming book titled: "How to Achieve Inclusive Growth," edited by V. Cerra, B. Eichengreen, A. El-Ga na iny, and M. Schindler, due for publication in 2021.
} 


\section{Contents}

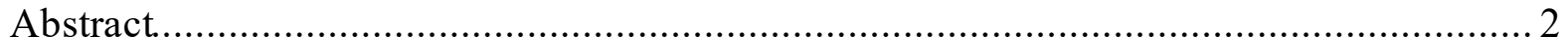

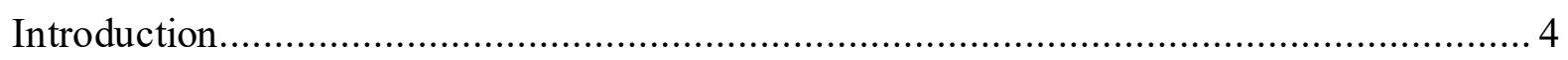

I. Youth Poverty and Unemployment............................................................. 4

A. Demographics and secular trends................................................................ 5

B. Young people in the labor market.................................................................. 7

C. Causes of youth vulnerability .............................................................. 10

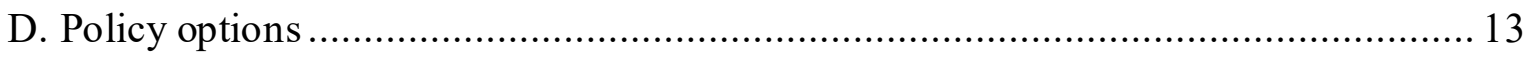

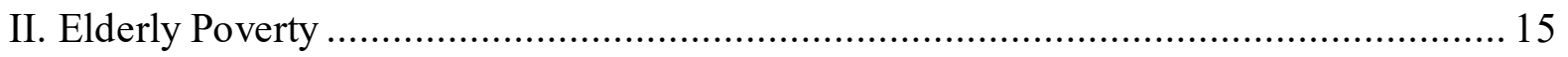

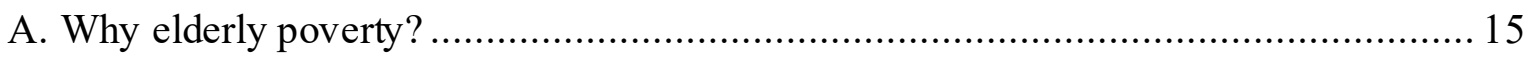

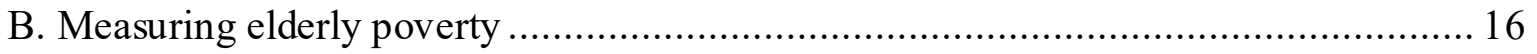

C. Facts on elderly poverty ............................................................................ 16

D. Sources of income for elderly people........................................................... 19

E. Policies to reduce elderly poverty .......................................................... 21

III. Intergenerational Mobility ............................................................................ 23

A. Measuring intergenerational social mobility ................................................ 25

B. Barriers and drivers of social mobility ...................................................... 28

C. Policies to promote intergenerational mobility ................................................. 29

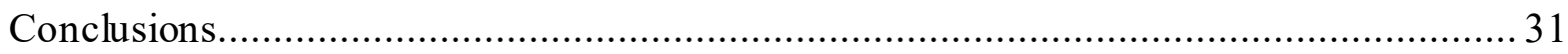

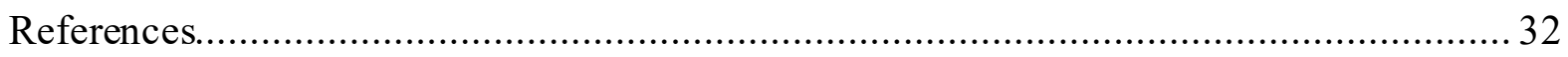

\section{Figures}

Figure 1. Youth Vulnerabilities ............................................................................ 6

Figure 2. Demographic Trends .................................................................. 7

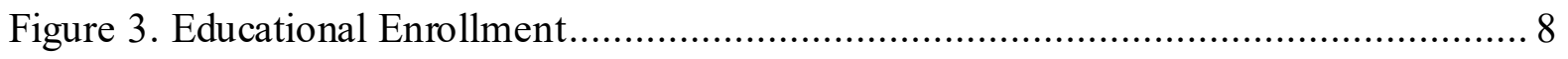

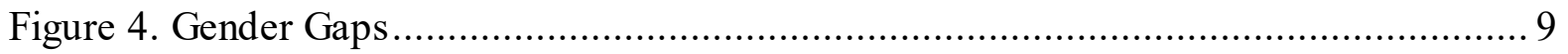

Figure 5. Elderly Poverty Rates (over 65), 2019 ...................................................... 17

Figure 6. Income Poverty Rates by Age: Elderly vs. Total Population........................... 17

Figure 7. Gini: Elderly vs. General Population....................................................... 18

Figure 8. Income Sources of Elderly People............................................................ 19

Figure 9. Pension Coverage for Older Persons ........................................................... 20

Figure 10. The Great Gatsby Curve .................................................................... 24

Figure 11. Intergenerational Mobility in Income .............................................. 26

Figure 12. Intergenerational Mobility in Education ............................................. 27

Boxes

Box 1. Youth Labor Market Integration in MENA ..................................................... 12 


\section{INTRODUCTION}

Inclusive growth refers to sharing economic benefits equitably across all segments of society, such as groups of people from different genders, ethnicities, and regions. Another important aspect of inclusion is the sharing of economic benefits across generations, both in the static dimension of people in different age groups at a point in time and the dynamic dimension of people from different generations over time. This paper analyzes the challenges and policy options to promote both static and dynamic generational inclusion.

At a point in time, the two main generational groups that are most vulnerable are the youth and the elderly. The youth have higher poverty rates, and they have significantly worse labor market outcomes than other groups in many countries. The elderly often rely on income and health care support from public systems that are under increasing strains due to demographic and other trends.

Turning to the intergenerational dimension, a key issue is the dependence of economic opportunity on resources and advantages passed from parents to their children. In some countries, intergenerational mobility has been falling in recent times, exacerbating the impact of inequality by thwarting opportunities for social advancement.

\section{YOUTH POVERTY AND UNEMPLOYMENT}

Youth worldwide are a vulnerable group. The transition from childhood to adulthood, and especially from school to work, presents multiple challenges that are critical for long-term livelihood outcomes. Young adults' prospects and outcomes are largely influenced by socioeconomic factors during their childhood, such as opportunities in terms of access to quality education and health services, geography, etc. As a result, disadvantaged youth are more at risk of being marginalized.

Youth are particularly vulnerable to poverty. Youth unemployment and inoccupation rates are higher than those of the adult population (Figure 1). Young workers are more likely to live in poverty than their adult peers (Figure 1d). Globally, 13 percent of working youth live in extreme poverty conditions (defined as living with less than $\$ 1.90$ a day), and another 17 percent live in moderate poverty (defined as living with less than $\$ 3.20$ a day). In LowIncome Countries (LICs), up to 40 percent of working youth live below the international extreme poverty line. In countries with well-developed social safety nets, these often tend to target different groups (e.g., elderly, families with children, etc.), leaving working-age youth more vulnerable to poverty. For example, in the United States, young adult poverty has increased over the past decades and is among the highest for any age cohort (Hawkins, 2019). Because young adults are more financially constrained (Figure 1c), economic downturns that translate into deteriorating living conditions often lead them to make decisions that further affect their prospects, such as prematurely ending their education or transitioning into low-quality jobs (with poor working conditions and low wages). In emerging and developing countries, this translates into high levels of informal jobs among 
youth. In advanced countries, in times of downturns, young workers may accept jobs that are below their skill levels, having a long-term impact on their human capital and subsequent opportunities in the labor market.

\section{Poor labor market prospects and lack of opportunities are a major source of concern} for young people and have spurred social discontent in many countries. Surveys of young adults around the world highlight youth concerns regarding difficult labor market prospects. For example, 45 percent of Arab youth see high unemployment as the biggest obstacle facing the Middle East, ${ }^{2} 69$ percent of young African cited unemployment as their main concerns, ${ }^{3}$ and 42 percent of youth surveyed in the European Union (EU) in 2017 said that employment should be a priority for the EU.

The covid-19 crisis disproportionately affects the youth. Recent survey-based research in the UK shows that young people were among the hardest hit by the coronavirus shock (Adam-Prassl and al., 2020). In particular, they were more likely to have worked fewer hours, earned less than usual, and lost their job in the four weeks through March 25, 2020, than adults. Data for the US shows that although the 16-24 years old cohort only represents 12 percent of all workers, they represent 24 percent of those employed in industries vulnerable to covid-19 (Kochhar, 2020). In addition, extended containment measures may affect educational outcomes and accentuate inequalities as online schooling content appears inadequate and sometimes inexistent. This is especially a risk in EMDEs where poorer populations do not have reliable access to the internet, increasing the risk of school dropouts, especially young girls.

\section{The transition from education to work is a critical period for youth that has} implications for long-term employment outcomes. Technology is rapidly changing work, requiring new skills and increased adaptability among workers. How youth fare in their first transition has implications for future job opportunities in an evolving labor market.

Entrenched youth exclusion deteriorates human capital, which in addition to creating a lost generation, can ultimately affect growth and productivity, hampering future economic prospects of countries.

\section{A. Demographics and secular trends}

\section{Youth represent a large share of the world's population and will soon transition to} working age. About 25 percent of the world's population is under the age of 15 (ranging from 17 percent in high-income countries to 42 percent in low-income countries). The working-age population has increased by almost 35 percent in the last two decades and is expected to continue to grow in many parts of the world (Figure 2).

This demographic trend presents opportunities, but it also poses challenges for labor markets around the world. In emerging and developing countries (EMDEs), the demographic transition can yield significant growth dividends as the increase in the workingage population decreases the dependency ratio and can boost income and consumption. In

22019 ASDA'A Burson-Marsteller Arab Youth Survey.

${ }^{3} 2016$ IPSOS African Youth survey. 
advanced countries (AEs), where aging populations are creating new challenges for the financing of social services and pensions, economic immigration can help alleviate the increasing dependency ratio. However, in EMDEs where unemployment rates are already high, and labor force participation is low, harnessing these benefits requires creating jobs not only for the millions of youth that will join the labor market in the coming years but also for the millions that have been excluded so far. In addition, the emigration of educated youth puts EMDEs at risk of a brain drain, i.e., of losing the human capital they have invested in.

Figure 1. Youth Vulnerabilities

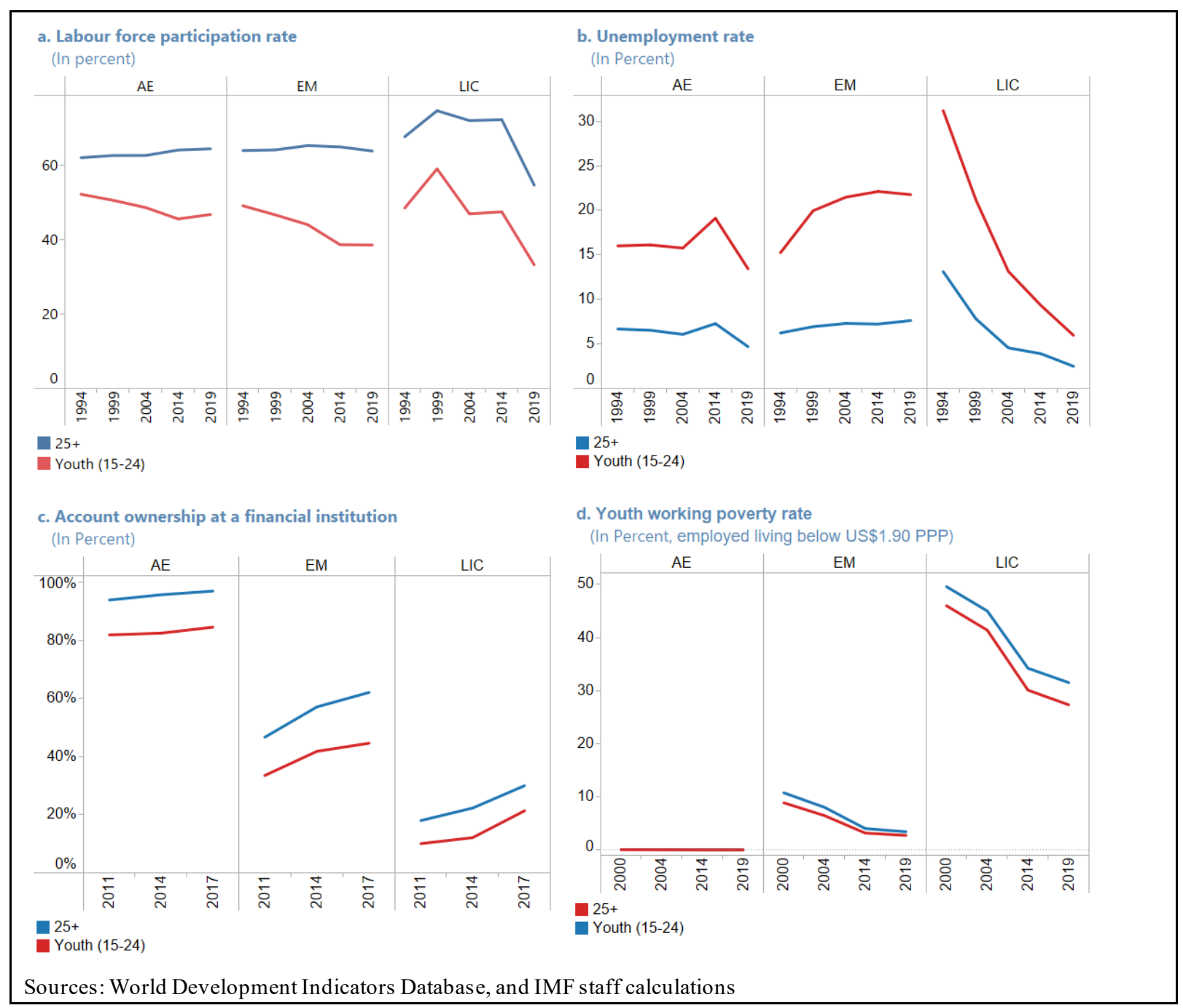

Technological progress and automation are changing the nature of work. More and more tasks are being automated, leaving workers vulnerable. AEs have been more vulnerable to the changing nature of work so far (Ahn and others, 2019). However, EMDEs can also be affected, especially if AEs decide to automate rather than delocalize activities such as light manufacturing (Anh and others, 2019; UNCTAD, 2017). For all countries, understanding how technology is changing the nature of work and workers and promoting flexible and adaptable economies and the labor force is critical to better prepare the next generation of workers for the evolving labor demand and better protect them (World Bank, 2019). 


\section{B. Young people in the labor market}

Young people everywhere are transitioning to the labor market later in life. Worldwide, secondary and tertiary education enrolment rates have increased by more than ten percentage points in the past decade and a half, resulting in a better-skilled labor force (Figure 3 ). As of 2017,36 percent of young men and 40 percent of young women were enrolled in tertiary education.

Figure 2. Demographic Trends

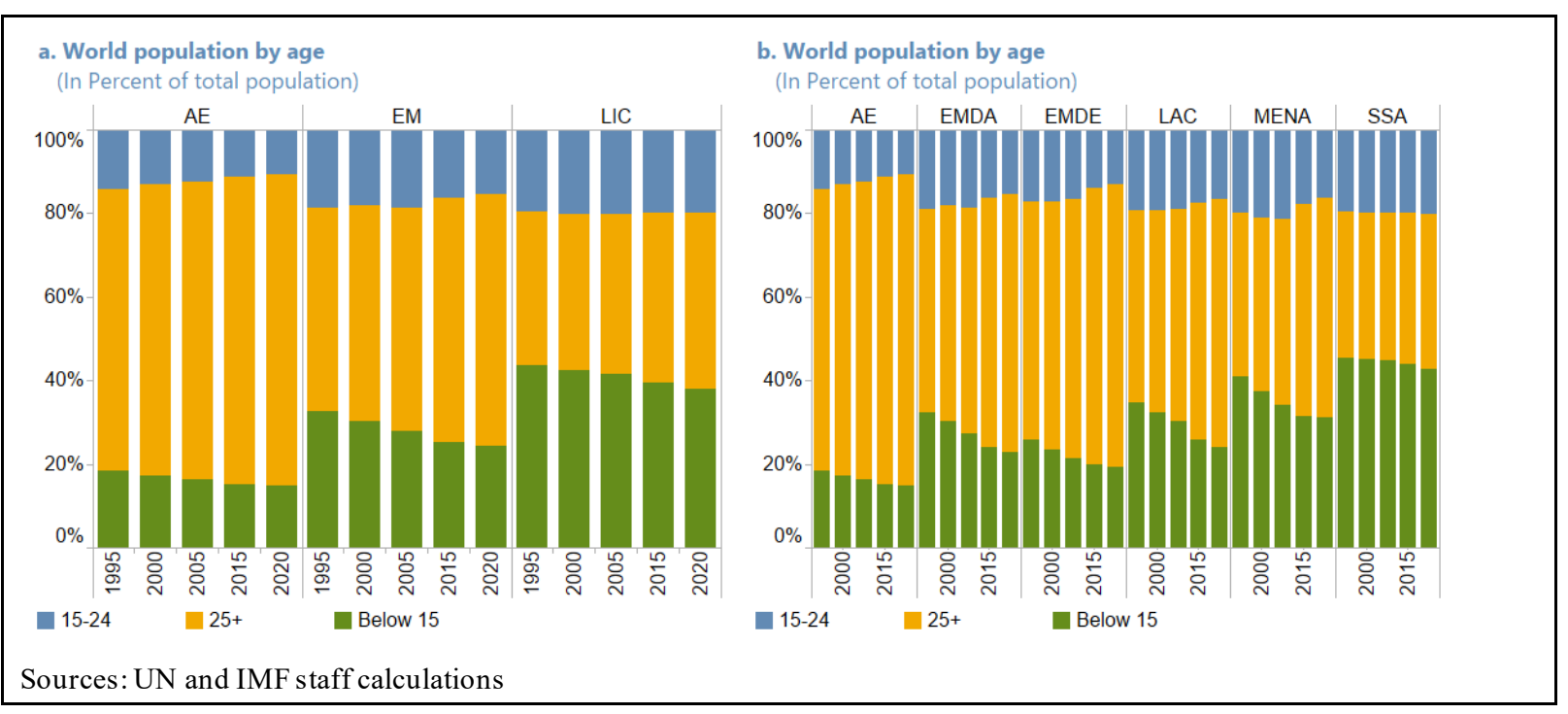

Youth unemployment is high at the global level. According to International Labor Organization (ILO) data, the unemployment rate of youth was nearly 14 percent as of 2019 , more than three times higher than that of the adult population, and reached a high of 27 percent in the Middle East and North Africa (ILO, 2020a). Higher turnover and unemployment among youth may reflect positive developments as youth gain experience through "trying out" different jobs, and they generally have fewer family responsibilities and can focus on building up their careers rather than on job security. However, unemployment is often not a choice, as reflected in high long-term unemployment rates among young people. Across OECD countries, about 18 percent of unemployed youth have been without a job for a year or longer. Youth in EMs leave education earlier, and they have longer transition periods to find a first job (Quintini and Martin, 2014; Matsumoto and Elder, 2010).

Youth inactivity is a persistent challenge. A large number of young people are still outside of the labor force for other reasons than studying (Figure 3c). According to ILO estimates, 22 percent of youth globally are not in employment, education, or training (NEET), ranging from 12 percent in AEs to 30 percent in MENA (see Box).

Young adults tend to have lower-quality jobs (Ahn and others, 2019; Cho and others, 2012; Quintini and Martin, 2014; Shehu and Nilsson, 2014). Wage employment remains high, around 54 percent globally (ILO, 2020), on par with the adult population. However, it is not anymore systematically associated with job security and social protection as nonstandard forms of work (temporary and part-time contracts, "gig" economy) has been 
increasing rapidly. Globally, the share of underemployed youth ${ }^{4}$ (Figure $3 \mathrm{~d}$ ) is three times as high as the equivalent share among adults (ILO, 2020b), ranging from around 18 percent in AEs to over 25 percent in EMs. In EMDEs, absent adequate social safety nets, a disproportionate share of young workers are employed in informal jobs (around 55 percent on average in EMDEs, excluding agriculture sector informal jobs according to Ahn and others, 2019).

Figure 3. Educational Enrollment

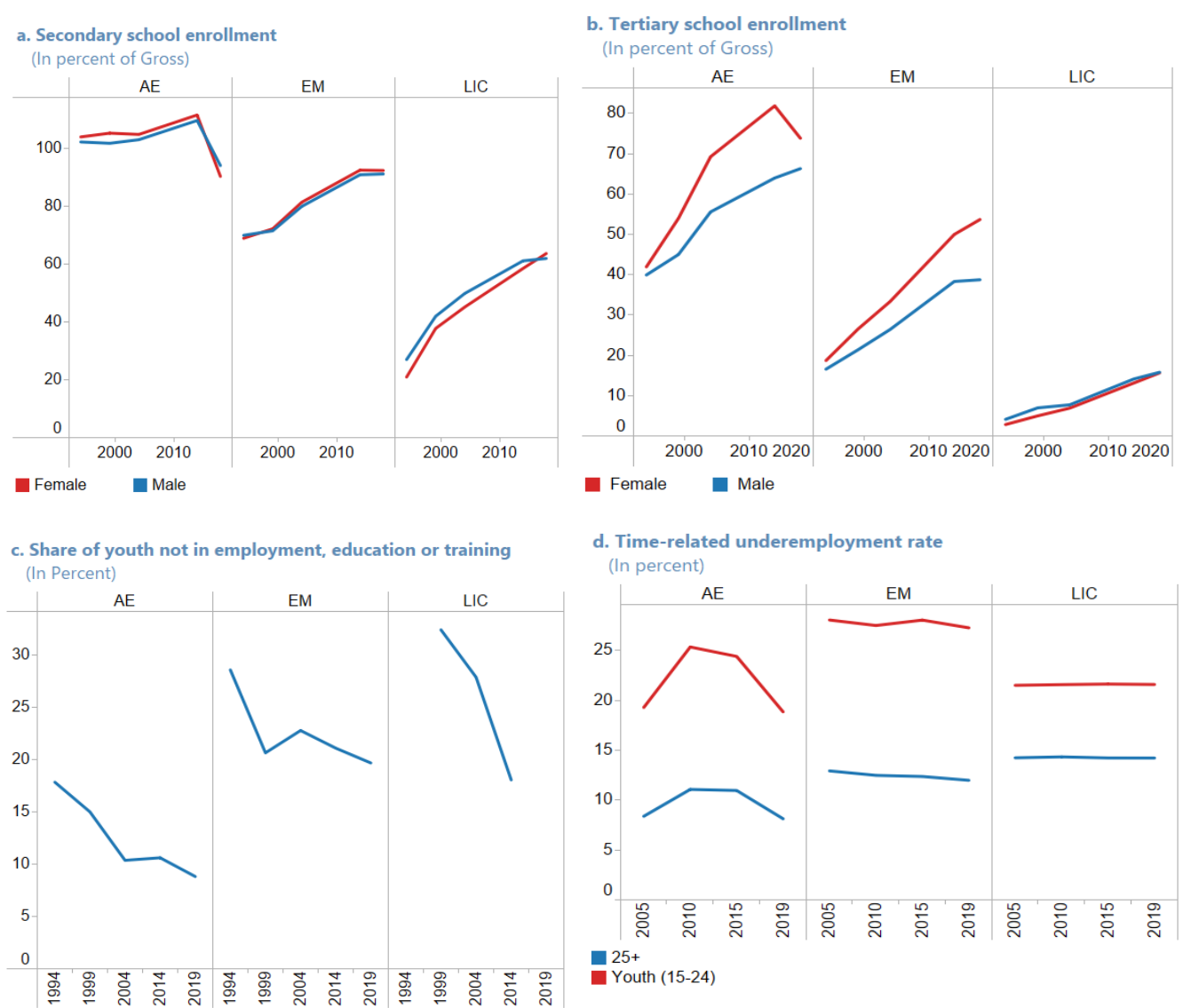

Sources: ILO data and IMF calculations

Wage inequality tends to be higher among youth. One evident factor is that educated youth starting their career will start at the bottom of the pay scale. However, the youngest cohorts with less education also typically work in lower-paying jobs. As a result, in the US, for example, the mean wage of 16-24 years old is about 65 percent that of 25-34 years old. Underemployment has also been associated with lower youth earnings. Because the most disadvantaged youth combine low education and low skills or experience, they find themselves at the bottom of the wage distribution and are more likely to experience poverty. As a consequence, wage inequality tends to be higher among youth than among the adult population, although it has decreased since the global financial crisis, driven by falling returns on tertiary education (ILO, 2020).

\footnotetext{
${ }^{4}$ A mea sure developed by the ILO to capture la bor market deficiencies such as people working less hours and earning less incomethan they would like and a re a vailable to or using their occupational skills incompletely.
} 


\section{Despite converging education rates, young women are still at a disadvantage in the}

labor market. Educational gaps have broadly closed, and young women nowadays have comparable educational attainments to young men. Nonetheless, young women have more difficulties finding jobs (Figure 4) than young men. As a result, young women are disproportionately represented among NEET (70 percent of youth NEET are young women). Progress has been achieved in recent years to reduce the gender gap in participation in EMDEs, but it remains significantly higher than in AEs (Ahn and others, 2019).

Additionally, even for young women who do find a job, evidence suggests that they take longer to find their first job than young men (Manacorda et al., 2017). Finally, the gender pay gap is lower among younger cohorts, as single young men and women tend to appear very similar to the employer, although not everywhere, often influenced by cultural factors. But it still exists, reflecting, in part, that young women are more likely to be under-employed and are more represented in low pay jobs and part-time work than young men.

Figure 4. Gender Gaps

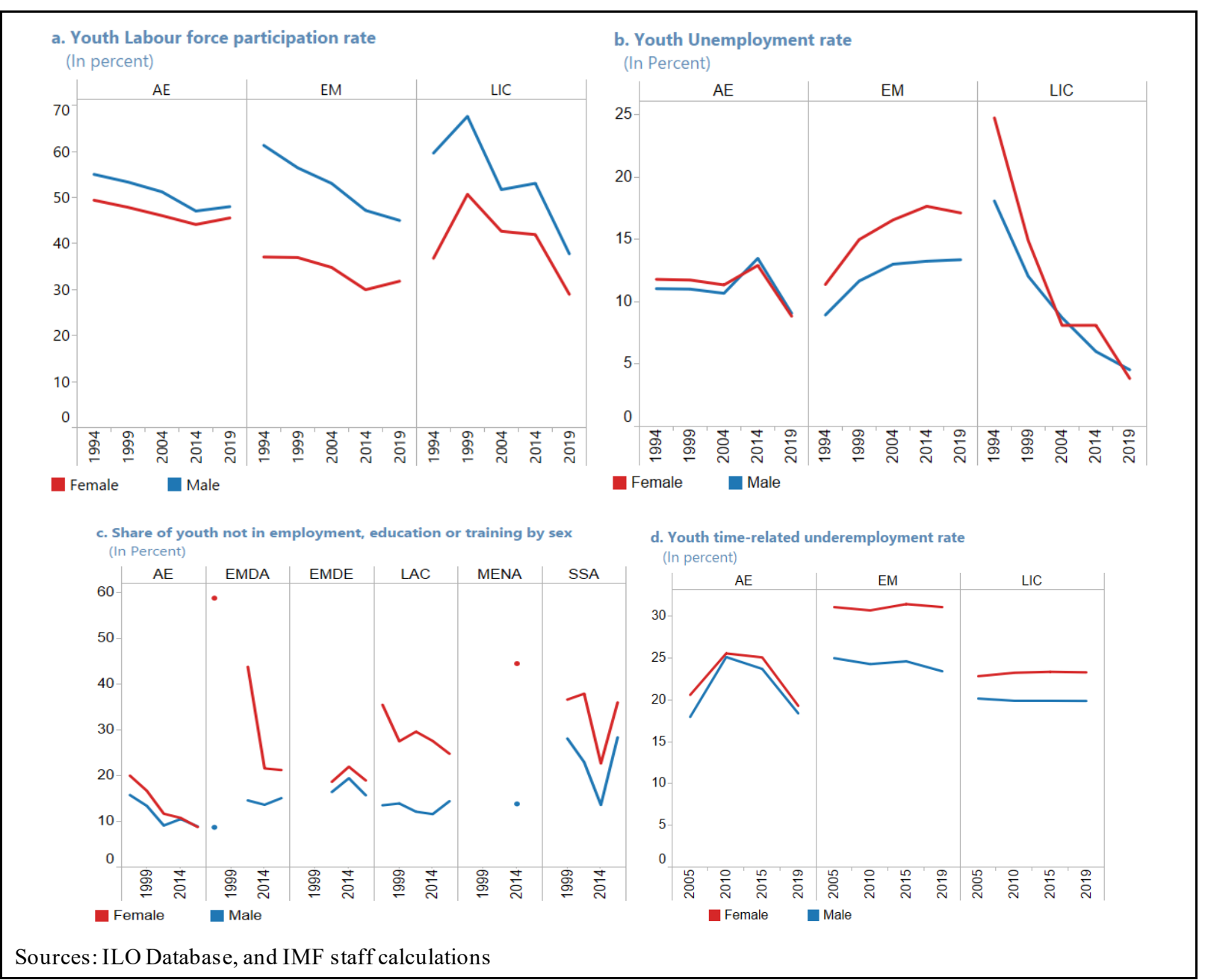




\section{Causes of youth vulnerability}

Young people are more vulnerable than adults to economic downturns. In times of economic downturns, youth often find themselves victims of the "last in - first out" rule because they are less experienced, have shorter employment tenures, and are more likely to have less secure contracts than adults. Studies based on advanced countries' labor markets have found evidence of lasting impacts for young people entering the labor market during a recession (Cockx, 2020). Depressed labor markets translate into lasting earning losses and persistence into lower-quality jobs, etc. The highly educated tend to be less affected than those with lower education, and more rigid labor markets are associated with higher persistence effects. In AEs, the labor market prospects of young people significantly worsened in the aftermath of the global financial crisis. The youth unemployment rate increased from 13 percent in 2007 to a peak of 18 percent in 2010-13. The NEET rate rose to 15 percent in 2010 from 13 percent in 2007. In EMDEs, youth labor market outcomes are also significantly affected by the economic cycle. In countries with weak social protections and widespread informality rates, the informal sector tends to act as a shock absorber when formal labor market demand decreases in downturns (Ahn and others, 2019).

But structural constraints explain a significant share of youth unemployment. All over the world, evidence suggests that youth take a long time, around two years, to find their first job, translating into high rates of long-term unemployment among people who have never worked (Manacorda and others, 2017). On the demand side, the lack of dynamism of the private sector in a context of dynamic demographic trends and slow economic transformations in EMDEs, at a time where educational attainment is increasing, present specific challenges for youth to transition to jobs that match their qualifications (Fox and Kaul, 2018). On the supply side, in some regions, duality such as preference toward public sector jobs also explain low youth employment rates among educated youth as those who can afford to stay unemployed (supported by their families) "queue" for these jobs.

A rigid labor market can make the transition to employment more difficult. As new entrants into the labor market, young people can be disproportionately affected by high labor costs (e.g. high minimum wages) and rigid employment protection (e.g., large severance payments) that are likely to discourage employers from hiring them in stable jobs (Quintini and Martin, 2014). There is evidence that this is associated with lower youth employment (Duval and Loungani, 2019). In addition, in AEs, this often translates into an increase in temporary contracts for youth, while in EMDEs, which offer fewer benefits and protection to workers, it often leads youth into informal jobs.

In general, longer education is associated with better labor market outcomes. Better education is associated with lower unemployment and inactivity rates, higher-quality jobs, and a better chance to transition to formal work in EMDEs (Shehu and Nilsson, 2014). However, the returns to education have been decreasing in some parts of the world, either through a weaker transition to work as labor demand has not kept pace with growingly educated labor supply (EMDEs) or through a combination of lower job quality and more expensive education (AEs). In this context, young people find it more difficult to get jobs 
than their parents (see the section on intergenerational mobility). As social mobility declines, transitioning to employment is growingly challenging for disadvantaged youth. In some countries, the quality of education has not always kept up with the changing labor demand, making young people ill-equipped to succeed in the labor market.

Gaps in opportunities explain the gender gap in labor market outcomes.

Young women still disproportionately face distortions and discriminations in the labor market, mobility constraints, the brunt of family obligations, and restrictions on their rights (ILO, 2020; Elborgh-Woytek and others, 2013; Gonzales and others, 2015; Shehu and Nilsson, 2014). Young women are also still underrepresented in some education and career streams such as STEM or vocational education and training programs. The fact that gender gaps tend to widen with marriage and more so with parenthood shows that there is still a very prevalent penalty for women in the labor market associated with their disproportionate contribution to household and family obligations. In addition, the lack of networks and role models, which in some regions play an important role in successful labor market transitions for youth, amplifies the constraints for young women. 


\section{Box 1. Youth Labor Market Integration in MENA}

The Middle East and North Africa (MENA) region has one of the lowest rates of employment globally. Just over one in every two adults' work. Less than one in every six women work, driven in large part by their low labor force participation, which stands at about 20 percent. Low overall employment rates also reflect high unemployment levels, especially among young people. The average unemployment rate for young people is around 30 percent.

Youth unemployment appears to be mostly of a structural nature. Studies have highlighted the MENA region more specifically as having structurally longer transition and overall poor labor market outcomes for youth ${ }^{5}$, often translating into high rates of long-term unemployment among people who have never worked ${ }^{6}$.

Both demand and supply factors explain poor labor market outcomes for youth. Skill mismatches, lack of dynamism of the private sector, and preferences toward public sector jobs are important factors behind youth dynamics in MENA labor markets ${ }^{7}$. High unemployment also appears to have been accompanied by growing inoccupation rates driven by discouragement. MENA countries all share several obstacles that limit job opportunities for young men and women, especially, low demand for skilled workers, unfavorable business regulations that do not promote entrepreneurship, and weak governance ${ }^{8}$.

As MENA countries have faced rising budget deficits and public debt, public sectors could no longer absorb the growing labor force. Public sector wage bills in MENA are higher than in any other countries driven by both higher civil service employees and higher wages and compensations. Inefficient hiring and compensation practices, significant wage gaps with the private sector, and a legacy of employers of the first resort have growingly translated into unsustainable public finances and labor market distortions 9 .

Socioeconomic backgrounds play an essential role in youth transition to the labor market. MENA labor markets are extremely segmented, and social networks ("wasta") have a prominent role in a job transition, creating inequalities of opportunity ${ }^{10}$. Unemployment is also positively correlated with education levels and parental wealth highlighting mismatches between the supply and demand for labor in the region (skills, expectations, etc.).

The gender gap in labor market participation is particularly acute in MENA. The overall unemployment rate of women has been more than doubled that of men, a pattern that holds among young generations. Young women are likely to drop out of the labor force after marriage, as privatesector jobs are often difficult to reconcile with family obligations ${ }^{11}$. Additionally, even for women who do find a job, their transition period is longer than for men.

\footnotetext{
${ }^{5}$ Assaa d, R. and C. Krafft(2016); Manacorda, M., and others (2017).

${ }^{6}$ Dimova and others (2016).

${ }^{7}$ Angel-Urdinola and Semlali(2010); Sieverding, M. (2012); Hassan and Sassanpoor(2008).

${ }^{8}$ Dibeh and others (2016); World Bank (2012).

${ }^{9}$ Ta mirisa, N. and others (2018).

${ }^{10} \mathrm{Krafft}$ and Assaad (2015).

${ }^{11}$ ILO (2018) and World Bank(2014).
} 


\section{Policy options}

\section{Designing and implementing reforms to support youth transition into the labor market is critical to foster sustainable and inclusive growth. Evidence suggests that to be most effective, strategies to foster youth integration into the labor market need to be broad-based, including education, labor market, and product market reforms, aiming at facilitating school- to-work transitions into good-quality jobs. Policies need to consider a large range of factors specific to country circumstances.}

Some critical areas of reform can be outlined for AEs and EMDEs. If some areas are common to all countries, the starting point is not the same. In AEs, educational attainments are higher, and social protection systems are stronger. Demographics trends are also more favorable for young people as the aging population retires. In these countries, reforms should aim at fine-tuning institutions and policies to better prepare and protect youth, especially disadvantaged ones, in rapidly evolving labor market environments. In EMDEs, there is a need to continue to improve the educational attainment of young people as well as to foster economic transformations that create enough jobs for increasingly educated youth, a multidimensional challenge that is particularly relevant for resource-rich countries. In the context of high informality and often weak social protection systems, supporting youth transition to good-quality jobs early in their career is critical.

Everywhere, young people need to be equipped with better and broader skills. This requires better education throughout their youth, starting with early childhood development and good quality primary education. This is especially important for disadvantaged youth, for which policies should aim at extending their stay in formal education as long as possible, for example, by providing direct cash transfers to their families (ILO, 2011). In EMDEs, it also means improving access to and quality of secondary education and in AEs focusing on retention through high school (Quintini and Martin, 2014). Young people also need access to digital and soft skills and to continuous learning to adapt to a constantly changing labor market. In this context, tertiary education and vocational studies especially need to modernize to provide youth with those needed skills. Although there is mixed evidence on the outcomes of vocational training, some studies have found that in countries such as Germany or Denmark, it has had positive impacts on youth integration into the labor market (Zimmermann and others, 2013). Generally, strengthening the link between education, training and work would support youth integration (ILO, 2011). Given the changes associated with automation and the need to build resilience in the face of pandemics, policies need to support young people in being rapidly adaptable to changing labor market needs and demand.

Flexible labor markets with social safety nets that aim to protect workers - not jobscan support youth employment. More flexible labor market institutions are associated with better outcomes for youth (Ahn and others, 2019). Labor market policies directed at protecting workers rather than jobs can limit distortions that put young people at a disadvantage. For example, reducing severance payments could help promote youth access to 
stable jobs (Purfield and others, 2018). In general, labor market regulations that reduce duality, facilitate workers' mobility, and unemployment protection systems that support workers' transition without raising the opportunity cost of work would all contribute to limit distortions to youth's integration. They are also particularly important in the context of the rapidly changing, technology-driven nature of work. In this context, unemployment insurance schemes should also aim at reflecting the reality of high turnover between periods of employment and unemployment for young people and find ways to protect them adequately. They also need to ensure that they adequately cover the self-employed (O'Higgins, 2017). Labor costs as measured by the tax wedge and minimum wages should be carefully set at a level that does not hurt youth formal employment opportunities (Banerji and others 2014; Purfield and others, 2018). On average, minimum wages have a slightly negative impact on youth employment, and the effect is larger in EMDEs than in AEs (O’Higgins, 2017). In all countries, addressing legal impediments for women's integration into the labor market and promoting family-friendly labor regulations such as family leave, childcare services, and flexible work arrangement is critical to reducing gender gaps.

\section{Targeted active labor market policies ${ }^{12}$ (ALMPs) can support youth employment,} particularly those more at risk of unemployment, such as disadvantaged youth. These programs are common in AEs and have increased significantly in Europe in the aftermath of the global financial crisis. In EMDEs, wage subsidy programs are less developed than in AEs. Given that, on average, youth in EMDEs have lower education than in AEs, training programs that help young people acquire skills (as in Latin America, for example) can be more effective for their integration into the labor market (O'Higgins, 2017). In LICs, wage subsidy programs are rare and mostly take the form of public employment programs in specific sectors such as public infrastructure maintenance (O'Higgins, 2017). In this context, they have low efficiency in improving employment prospects when they do not contribute to building skills (and they sometimes carry a negative stigma) but have also been used as a transitory income support mechanism. Programs aimed at promoting self-employment and entrepreneurship have shown the most positive results among ALMPs in EMDEs, especially when they are combined with other policies in the areas of social protection, access to finance, etc. (O’Higgins, 2017).

\section{Successful implementation of cost-efficient programs tends to require a high} administrative capacity to target, implement, monitor, and evaluate outcomes which can be more challenging in EMDEs than in AEs. There is evidence in EMDEs, in MENA, for example, that programs suffer from fragmentation, poor administrative capacity, flaws in program design, bottlenecks, and lack of accountability that hamper programs' effectiveness (Angel-Urdinola and Leon-Solano, 2013). However, digitalization can offer opportunities to strengthen public employment services at low costs through online platforms in both AEs and EMs and even in LICs, where mobile phone penetration is high (ILO, 2020). Globally,

\footnotetext{
${ }^{12}$ Active la bor market policies a re public programs a imed a thelping a target population of unemployed people finds work through income support, job search services or tra ining and skills building.
} 
evidence shows that better targeting, medium duration, and a combination of wage subsidy and training have the most cost-effective results (O'Higgins, 2017, Levy-Yeyati and others, 2019). Recent evidence also suggests that programs targeted at disadvantaged youth are more effective (O'Higgins, 2017). ALMPs often need to be combined with other policies covering associated constraints to bear fruits. For example, ALMPs that target youth entrepreneurship needs to be associated with policies to strengthen access to credit. To benefit more young women (who are generally covered dejure by programs but de facto under-represented), ALMPs need to be combined with measures to promote flexible work arrangements. In general, ALMPs have weaker results where job creation is lackluster.

Reducing informality should be part of a broader policy strategy to improve job quality in EMDEs. Informal jobs in EMDEs are the norm for many youths. Because of the "signaling" effect of early labor market experiences, policies aimed at reducing informality should target interventions into preventing youth entry into informal jobs by aiming at improving young people's first experience in the labor market. First jobs programs have been developed in Latin America, for example, focusing on providing young people with good quality apprenticeship or internship opportunities or hiring subsidies and special arrangements for youth employment (O'Higgins, 2017). Improving the productivity of the informal sectors (including agriculture), by implementing measures to support human capital build-up and creating enabling environments towards formality (market access, regulations, access to finance, etc.) can also contribute to decreasing youth exclusion and poverty.

Fostering private sector development in EMDEs, especially SMEs, is critical to creating more jobs for growing working-age populations. In many parts of the world, growingly educated youth has been discouraged by the lack of job opportunities. Creating enabling environments for private sector activity to thrive and create jobs is critical. Measures targeted at SMEs and promoting entrepreneurship, such as access to finance, could help support youth transition to work. Young people are tech-savvy, and they can also benefit from technologydriven change if given adequate incentives and opportunities.

\section{ELderly POVERTy}

\section{A. Why elderly poverty?}

The share of elderly people in the world population is now higher than ever and rising. The world population over the age of 65 is projected to increase from 9 percent in 2019 to 16 percent by 2050 (UN, 2019). Elderly people face greater risks of becoming or remaining poor due to reduced options to work and more health issues. If elderly people have inadequate savings and social benefits, they can be vulnerable to economic insecurity and poverty, with limited options to escape. 
The COVID-19 crisis amplified the existing vulnerabilities of the elderly across the world. With the fatality rates for older people several times the global averages and limited access to essential health services in many countries, elderly people face a range of additional risks from the pandemic, including age discrimination in accessing health care services, neglect, and violence (UN, 2020, Policy Brief: The Impact of COVID-19 on older persons). The pandemic may also lead to a scaling back of critical services unrelated to COVID-19, further increasing risks to the lives of older persons (WHO, 2020).

\section{B. Measuring elderly poverty}

There are several measures of elderly poverty and inequality. Absolute poverty rates show the percentage of elderly people living below the poverty line, whereas relative measures assess the distribution of poverty within the elderly group (horizontal inequality) or relative to other age groups (vertical inequality). For instance, horizontal inequality by income tends to be higher for countries with large informal sectors and relatively generous formal pensions. ${ }^{13}$ Vertical inequality can provide an insight into the relative situation of older people, as many low-income countries with a high absolute elderly poverty rate may have an even higher poverty rate for other age groups (Evans and Palacios, 2015).

Global estimates of poverty rates among older people are limited. With the absence of an international harmonized database on age-related poverty, the evidence is mainly limited to regional or country-level databases. In addition, most of the measures rely on countryspecific thresholds, which are not easily comparable across countries, particularly when comparing developed and developing countries. For example, the OECD defines elderly poverty as income below half of the national median household income, which does not necessarily imply a low standard of living.

\section{Facts on elderly poverty}

The poverty rates for older people vary significantly across countries. In OECD countries, elderly poverty rates (over 65) averaged 131/2 percent in 2017, compared with 12 percent for the population as a whole (OECD, 2019) (Figure 5). However, there are significant differences across countries. The poverty rates exceeded 40 percent in Korea, were above 30 percent in Estonia and Latvia, and more than 20 percent in Australia, Lithuania, Mexico, and the United States. By contrast, the Czech Republic, Denmark, France, Iceland, the Netherlands, Norway, and the Slovak Republic have the lowest relative poverty rates, below 5 percent. These differences reflect many factors, including overall poverty rates in a country, pension coverage, family structure, and societal preferences in designing social transfer schemes. Although no harmonized databases exist for developing economies, higher overall poverty rates, larger informal sectors, and lower pension coverage suggest that elderly poverty rates on average are higher than in developed countries.

\footnotetext{
${ }^{13}$ Low pension coverage exacerbates income inequality and may result in a regressive redistribution of resources from low- to high-income individuals.
} 
Figure 5. Elderly Poverty Rates (over 65), 2019

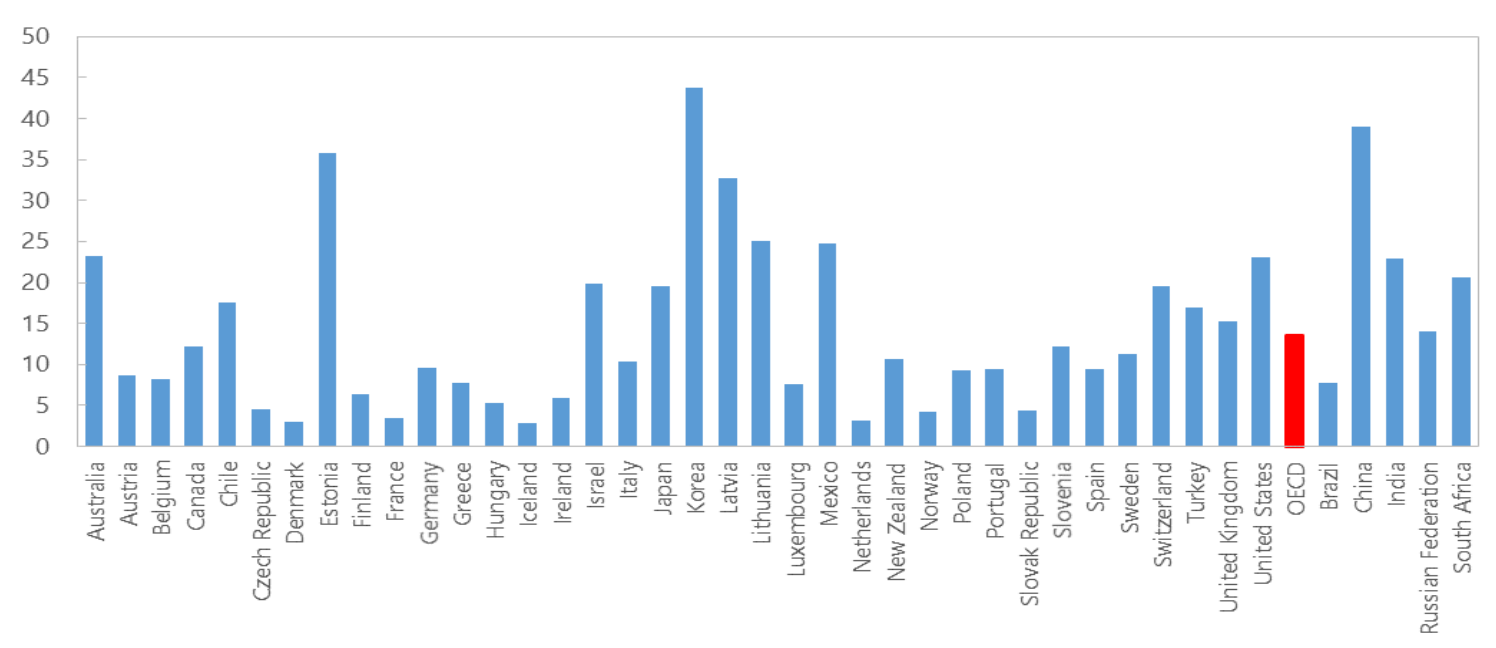

Source: OECM Income Distribution Database. http://www.oecd.org/social/income-distribution-database.htm

Incomes of older people relative to the rest of the population also differ depending on pension coverage and the adequacy of old-age social protection systems. For the OECD countries, older people fare relatively better than the rest of the population in 20 countries, including France, Slovakia, and the Netherlands. In Greece, Italy, and Spain, incomes for the elderly are above 90 percent of the national average because of the relatively generous pension schemes (Figure 6). By contrast, in Korea, Estonia, Latvia, and Australia, older people are much more likely to be poor. For G20 counties beyond OECD, elderly poverty rates are high in China and India, 39 percent and 23 percent, respectively, while Brazil has a much lower elderly poverty rate (OECD, 2019).

Figure 6. Income Poverty Rates by Age: Elderly vs. Total Population

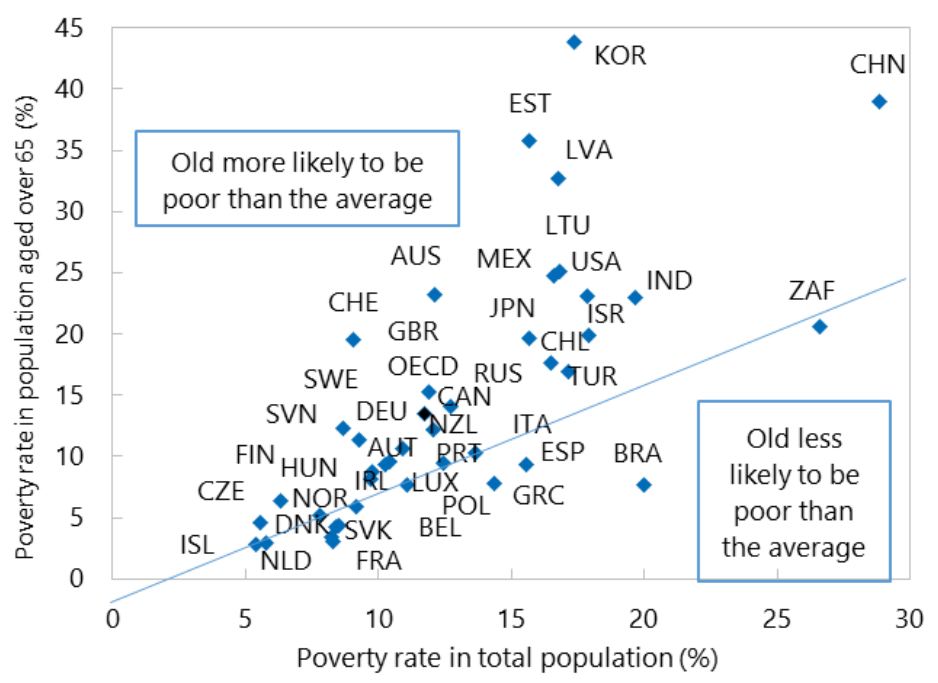

Source: OECM Income Distribution Database. 
For developing countries, relative poverty levels depend on demographics, pension coverage, and cultural arrangements. Older persons tend to be poorer than the general population in many African countries and are more often less poor in Latin America (UN, 2017, Ageing report). Kakwani and Subbarao (2005) find that for Sub-Saharan African countries, older persons are poorer than other age groups. In Zambia, for example, 80 percent of people aged 60 years or over were below the poverty line compared to 67 percent national average. In contrast, Evans and Palacios (2015) found that in the majority of countries - out of their sample of sixty developing countries-elderly people are less likely to be poor than children.

Within the elderly group, women and "very old" are more likely to be poor, and there are significant income inequalities in many countries:

- Older women are at greater risk of poverty than older men in all OECD countries where breakdowns are available (except Chile), with the average old-age poverty rate for women at nearly 16 percent versus about 10 percent for men (OECD, 2019). This likely reflects longer life expectancy and a lower labor force participation because of shorter and interrupted careers due to childbearing and caring.

- As the very old (over 75) people are more likely to have spent their savings, have fewer opportunities to work, and more need age-appropriate health services, in most OECD countries, the poverty rates are higher for "very old," averaging 16 percent. In Korea, Estonia, and Latvia, this difference is particularly high, reflecting low pension indexation. In addition, in Korea, where the pension system is still maturing, younger generations get higher pension benefits.

- While for the majority of OECD countries, income inequality among the elderly is lower than for the general population due to redistributive features of first-tier pension benefits and other schemes, in Mexico, Korea, and the US, elderly inequality is higher than that for the general population. For China and India, income inequality for the elderly also markedly exceeds that for the total population (Figure 7).

Figure 7. Gini: Elderly vs. General Population

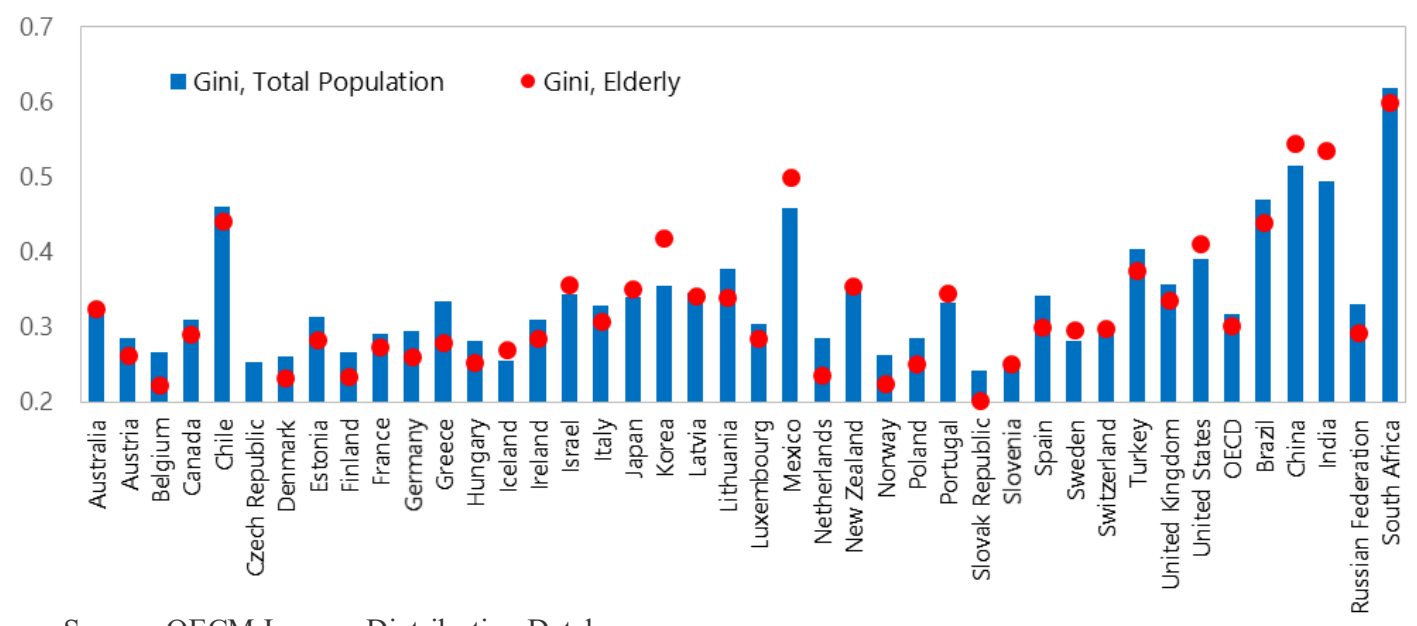

Source: OECM Income Distribution Database. 


\section{Sources of income for elderly people}

Pensions remain the main source of income for elderly people. The main sources of income for old can be broadly classified into five categories: public transfers (pensions, resource-tested benefits, etc.), occupational transfers (pensions based on employment), savings, work, and intra-family transfers (Figure 8). For the OECD countries, public and occupational transfers account for about two-thirds of the total income (OECD, 2019). For some countries, public pensions and transfers account for more than 80 percent of income (Hungary, Belgium). In contrast, in Mexico, public transfers are as low as 6 percent (as only 35 percent of workers are covered by public pensions). Work is important in many countries (Mexico, United States, Korea) due to several factors. For some countries, the pension age is higher than 65 years (US); for others, people keep on working to fill gaps in contribution histories or to obtain better incomes over retirement. Also, as incomes are measured for households, older people draw on the earnings of younger family members in multigenerational households (Korea). However, intra-family transfers to the elderly have been declining in many countries. In Korea, for example, fewer young people believe that they are obliged to support their parents (Kim, 2014). ${ }^{14}$ A study for advanced economies shows that in the U.S., Germany, and Italy, elderly parents are more likely to support their adult children than vice versa. There are also sharp differences across income groups. It is more likely for adults with lower annual household incomes to support their aging parents than for those with higher incomes (Pew Research Center, 2015).

\section{Figure 8. Income Sources of Elderly People}

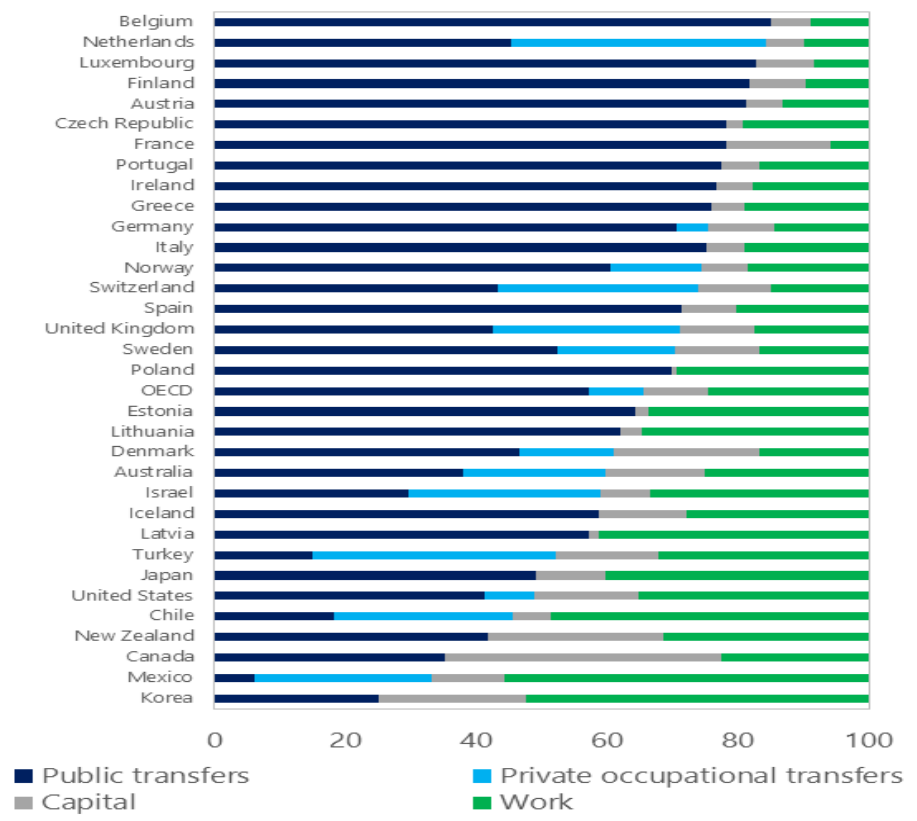

Source: OECM Income Distribution Database.

\footnotetext{
${ }^{14}$ In Korea, the proportion of private transfers in total retirement income among the elderly decreased from 55 to 45 percent between 1990 and 2008 .
} 
At the global level, 68 percent of people above retirement age receive some pension, ${ }^{15}$ either contributory or non-contributory (ILO, 2017) (Figure 9). However, the coverage varies significantly across the regions and income levels. While the coverage rates are close to 100 percent in developed countries, in Sub-Saharan Africa and Southern Asia, less than onequarter of elderly people receive pensions, depending heavily on family support arrangements. In addition, the level of pensions - and other social benefits in general - also vary across countries. For OECD pensions, the average replacement rate ${ }^{16}$ is around 53 percent at the age of retirement, falling to 47 percent at the age of 80 due to below wage growth indexation. Many developing countries have introduced social pensions to address the low insurance coverage of the elderly (Zouhar et al., forthcoming). ${ }^{17}$ Social pensions globally cover almost 35 percent of the old-age population.

Figure 9. Pension Coverage for Older Persons

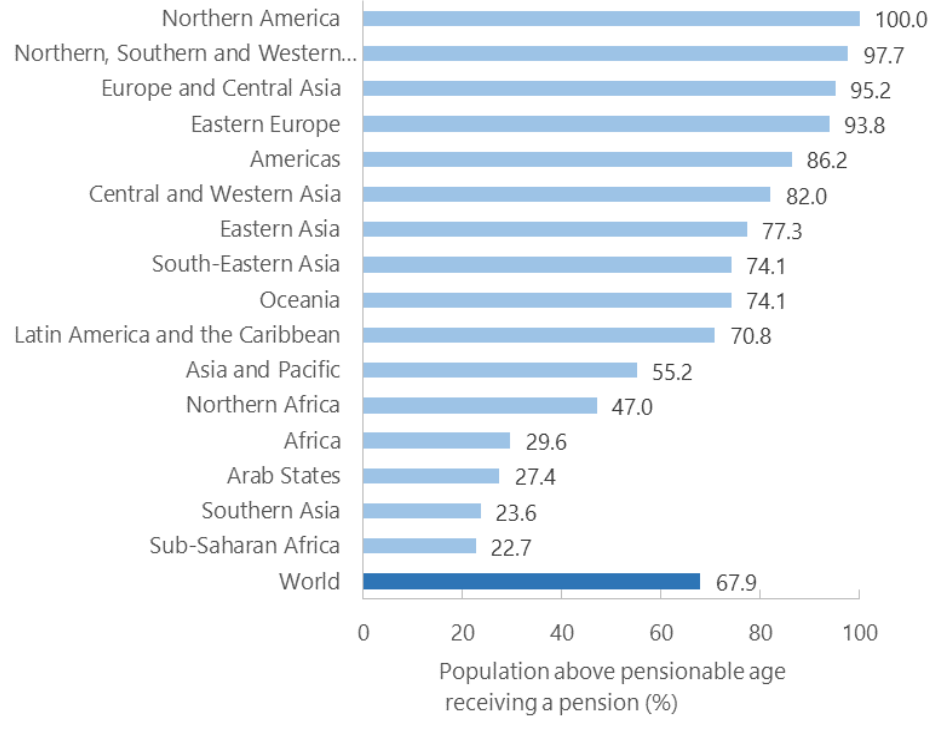

Source: ILO, World Social Protection Database, and national sources.

Income sources can largely explain the variation of poverty rates and income levels for older people across countries. The elderly are relatively better off in countries with higher levels and broader coverage of public and occupational pensions and higher social transfers related to health care. Income composition also changes along with the income distribution: older people at the bottom of the income distribution are more likely to derive their income entirely from public transfers, while capital and private pensions are more important for the top of the income distribution. The adequacy of retirement benefits depends not only on cash benefits provided but also on the costs of essential services such as health care. Countries

\footnotetext{
${ }^{15}$ Coverage for women is somewhat lower than that for the entire population at 64.1 percent, largely reflecting lower labor forceparticipation and overrepresentation among self-employed (ILO, 2017).

${ }_{17}^{16}$ Defined as a ratio of pension to pre-retirement earnings.

${ }^{17}$ Social pensions a renon-contributory benefits that are tax-funded and target the old-age population. They can be universal or means-tested.
} 
with large informal sectors not covered by universal retirement benefits ${ }^{18}$ experience higher elderly poverty rates.

\section{Demographic and economic trends, such as longevity and population aging, can have a significant impact on elderly poverty in the future:}

- The pace of world population aging is accelerating. Projections indicate that between 2019 and 2050, the number of elderly people will double. Population aging that has already affected most of the developed economies is expected to spread to developing countries at a substantially faster rate than it occurred in developed countries. The number of people aged 80 years or over - the "oldest-old" - is growing even faster and is expected to almost triple by 2050 . In the middle of the century, two out of every three oldest-old persons will be living in developing regions, countries with still large informal sectors, not covered by public pensions and transfers (UN, 2019 Ageing report).

- Each successive cohort of older persons is expected to live longer and possibly also have fewer adult children as potential sources of support in old age. In 2015, there were 7 people in the traditional working age for each older person aged 65 years and over in the world. By 2050, this number will be halved. At the same time, with urbanization and the transformation of many traditional family ties, more elderly are expected to live in nuclear households without family support (Kim, 2014).

- Population aging costs put pressure on public pension and health care systems, affecting fiscal sustainability. As a result, many countries are reassessing elderly benefits and transfers, making them less generous (EU 2012; IMF 2014). These reforms often include raising retirements' ages or lengthening required years of service, as well as reducing replacement rates. The potential negative impact of these reforms on elderly poverty can be sizable (Shang, 2014). ${ }^{19}$ Longevity will also increase the demand for health care services, particularly long-term care, which is not adequate in many countries (ILO, 2017, and WHO, 2015). ${ }^{20}$

\section{E. Policies to reduce elderly poverty}

\section{Policies needed to alleviate elderly poverty vary substantially across countries.}

In countries with comprehensive and mature systems of social protection and aging populations, policies should maintain a good balance between financial sustainability and pension adequacy. In countries with still limited pension coverage for elderly people and high levels of informality, policies should aim to broaden the coverage while ensuring the sustainability of social schemes. Polices to facilitate employment opportunities for elderly

\footnotetext{
${ }^{18}$ Universal retirem ent benefits a re usually granted based on a ge and residence.

${ }^{19}$ Shang estimates the relationship between public pension replacement rate s and elderly poverty and finds an ela sticity of about - 0.4 . In addition, Shang finds that reforms will disproportionally a ffect the poorest part of the elderly population.

${ }^{20}$ In many countries, a ccess to health services is limited and health workers may have inadequate tra ining to deal with issues common in old age.
} 
workers and to reduce gender inequality in pensions are relevant across all countries. Finally, improving health care affordability and services for the old is essential to maintain living standards for elderly people (ILO 2017, UN 2017, UN 2020).

- Countries that are planning or undergoing austerity pension reforms can mitigate the adverse impact on older people by adjusting the design of social security systems to support the elderly with lower incomes. This could be done, for instance, by reducing replacement rates for public pensions only for higher-income retirees, introducing universal social benefits, such as social pensions, or by targeting assistance to the poor. However, these policies should be weighed against potential adverse effects on labor markets (Shang, 2014).

- Countries with a large informal sector and low pension coverage could rely on several measures to broaden the coverage sustainably. These measures can include policies to increase the formal sector by, for example, incentivizing firms to use formal contracts, or by designing social assistance in a way that makes contributory schemes more beneficial for workers (Figliuoli et al., 2018). ${ }^{21}$ Also, efforts could be made to increase coverage for the lower-skilled and less-educated by, for example, automatic enrollment in voluntary pension plans (Benartzi and Thaler, 2013).

- With increasing longevity, policy measures should also support labor force participation for older people. These policies should focus not only on postponing the formal retirement age but also on creating incentives and opportunities to keep older workers with accrued pension rights in employment and on facilitating flexible working arrangements. Health care and training can maintain the productivity and employability of older workers (Figliuoli et al., 2018).

- As in many countries, women are disadvantaged in the wages they earn, policies should aim to reduce gender gaps in pensions. Potential measures could include using more progressive pension schemes, compensating women for "lost" years due to childbearing and caring, and increasing survivor benefits as women tend to live longer. In addition, policies that help to promote labor force participation by women - for example, by improving childcare benefits - could result in higher contributions and higher replacement rates upon retirement (Shang, 2014).

- Policies to improve access to universal health coverage, including long-term care protection, are essential for maintaining living standards for elderly people. Even before the COVID-19 crisis, as many as half of older persons in some developing countries did not have access to essential health services. The pandemic may also lead to a scaling back

\footnotetext{
${ }^{21}$ Since workers may choose between formal and informal employment opportunities based on the perceived value of future benefits from formal em ployment rela tive to current contributions, pension schemes may be designed in a way that increases incentives to participate.
} 
of critical services unrelated to COVID-19, further increasing risks to the lives of older persons (WHO, 2020). A simple increase in coverage may not be sufficient to address the needs of the aging population. Even in high-income countries, health systems are often better designed to cure acute conditions than to manage and minimize the consequences of the chronic states prevalent in old age.

\section{INTERGENERATIONAL MOBILITY}

Socioeconomic status at birth influences prospects of employment, health, and education outcomes, as well as other opportunities that are important for our wellbeing. This is shown by a number of studies about social mobility. For example, in OECD countries, children whose parents did not complete secondary school have only a 15 percent chance of going to university. At the same time, children with at least one parent with tertiary-level education have a 60 percent chance of making it to university. ${ }^{22}$

The relationship between the parents' and adult children's socioeconomic positions describes intergenerational social mobility. There is a difference between absolute and relative intergenerational mobility:

- Absolute intergenerational mobility compares the living standards across generations and looks at the share of children with higher living standards as adults compared with their parents.

- Relative mobility, or social mobility or fluidity, measures the probability that a child will attain a different economic status than that of their parents.

In this sense, social mobility is about ensuring that every individual has the opportunity and a fair chance of achieving their potential regardless of their family background. Relative intergenerational mobility and social mobility are used interchangeably and are the main focus of this section.

Citizens and governments are increasingly worried that younger generations will have fewer opportunities for upward social mobility than preceding generations. For example, in the UK, according to the Social Mobility Bathometer, a national survey of over 5 thousand people, revealed that 40 percent of respondents think that it is getting harder for people from less advantaged backgrounds to move up in British society, while only 21 percent think the opposite is true. ${ }^{23}$ In the US, about half of 30 -year-olds in 2016 were earning less than their parents earned at the same age. The data on historic trends supports these concerns. OECD estimates that it could take on average four to five generations for

${ }^{22}$ OECD, 2018.

${ }^{23}$ UK Social Mobility Barometer, 2018, https://assets.publishing.service.gov.uk/government/uploads/system/uploads/attachment data/file/766797/Socia 1 mobility barometer 2018 report.pdf 
children from a family in the bottom decile of the income distribution to reach the average income in OECD countries. This estimate ranges from two generations in Denmark to nine and eleven generations in Brazil and South Africa. ${ }^{24}$

Social mobility goes both upward and downward. "Sticky floors" refer to the low upward mobility at the bottom of the income distribution. At the same time, children from privileged families are much less likely to experience downward mobility: the ceilings are "sticky," too.

Intergenerational mobility is closely related to equality of opportunity. Economies with more unequal opportunities tend to have lower intergenerational mobility. Intergenerational mobility can be considered as one of the possible indicators of inequality of opportunity. ${ }^{25}$

Countries with higher income inequality tend to be countries with low intergenerational mobility. This relationship is commonly referred to as "The Great Gatsby Curve" (Figure 10). There is limited knowledge of the causal relationship between the two. Low mobility can be both a cause and a consequence of greater inequality. For example, inequalities in socioeconomic outcomes determine access to opportunities in education, health, and the labor market and, thus, influence the potential for social mobility.

Figure 10. The Great Gatsby Curve

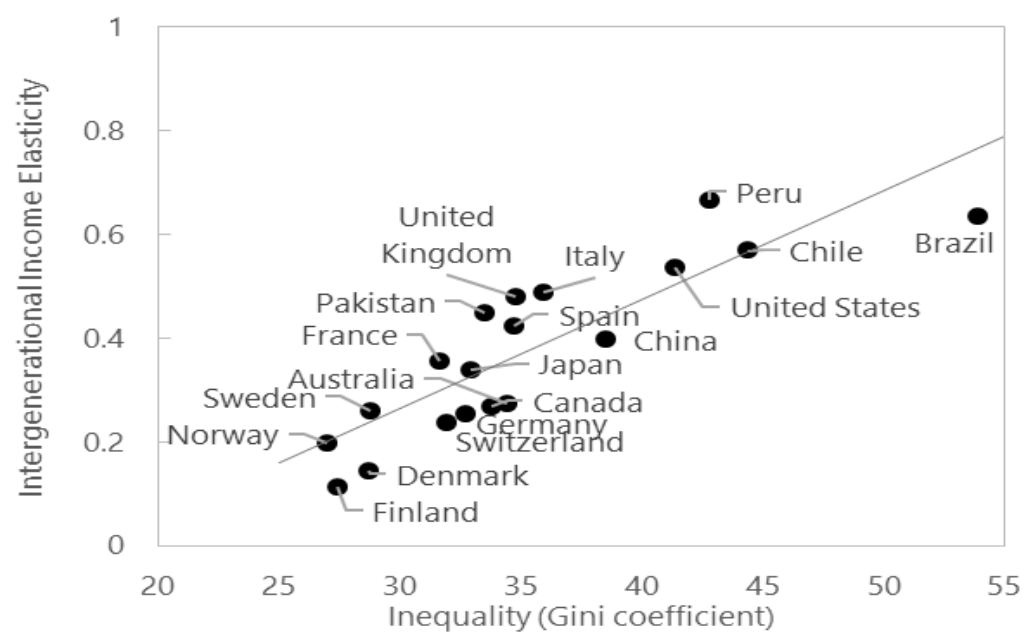

Sources: World Bank Development Indicators, latest available.

Global Database on Intergenerational Mobility (GDIM), 2018. Development Research Group, World Bank.

Lack of social mobility can have a negative impact on economic growth. As the OECD explains, a lack of upward mobility among individuals at the bottom of the income distribution means a loss of potential talents and investment opportunities. ${ }^{26} \mathrm{In}$ other words,

${ }^{24}$ OECD, 2018.

${ }^{25}$ Stiglitz, J., J. Fitoussi and M. Durand (eds.)(2018), For Good Measure: Advancing Research on Well-being Metrics Beyond GDP, OECD Publishing, Paris.

${ }^{26} \mathrm{OECD}, 2018$. 
inequality of opportunity prevents people from realizing their economic potential. The World Economic Forum estimates an opportunity cost of low social mobility based on the findings of its Global Social Mobility Report. The report suggests that if countries improved their performance according to the Global Social Mobility Index by 10 points, the global economy would gain an additional 514 billion USD per year (in PPP terms), all else being equal. ${ }^{27}$ This gain could be as large as 14.5 billion USD in Brazil, 103 billion in China, 18.5 billion USD in Germany, 42.8 billion USD in India, 17.8 billion USD in Russia, and 3.4 billion USD in South Africa.

\section{Perceived and actual mobility affects life satisfaction, social cohesion, and policy} preferences. Studies suggest that prospects of upward social mobility positively influence people's life satisfaction and well-being. Perceptions about equality of opportunities can reduce the likelihood of social conflict ${ }^{28}$, while inequality of opportunity is associated with lower levels of support for the market economy and democracy. ${ }^{29}$ Pessimism and optimism about social mobility are significantly correlated with people's preferences for redistribution policies. ${ }^{30}$

\section{A. Measuring intergenerational social mobility}

Intergenerational mobility can be analyzed in terms of various outcomes, such as earnings, education, occupation, wealth, or health. It is also a concept that may be difficult to measure with a single indicator. Social and economic mobility should be considered in combination with measures of poverty and inequality.

Intergenerational mobility of earnings measures the persistence of income between generations. Relative mobility in earnings can be measured by calculating the elasticity of intergenerational earnings (IGE). For example, consider the linear parent-child regression of the form:

$$
y_{i, \text { child }}=a+b y_{i, p a r e n t}+e_{i} \quad \text { (1) }
$$

The coefficient $\boldsymbol{b}$ represents the elasticity with a higher number implying that it is more difficult for an individual to move outside their income class. An elasticity of zero means the highest social mobility where a child's adult outcomes are not related to the status of their parents at all. If elasticity is 100 percent, all life outcomes of a child are fully linked to the socioeconomic status of their parents.

Based on the estimates from the World Bank's Global Database of Intergenerational Mobility (GDIM), income mobility appears to be lower in low- and middle-income countries and higher in high-income countries (Figure 11). For example, in high-income countries, an average IGE was estimated at around 35 percent. The highest income persistence was

\footnotetext{
${ }^{27}$ World Economic Forum, 2020, The Global Social Mobility Report.

${ }^{28}$ OECD, 2018.

${ }^{29}$ EBRD, 2016.

${ }^{30}$ Alesina, A., et a 1., 2018.
} 
estimated in countries in Latin America and the Caribbean, with an IGE of around 90 percent.

There are notable differences within income or regional groups. The elasticity in OECD countries varies from below 20 percent in the Nordic countries to 70 percent or more in emerging market economies. ${ }^{31}$ Among high-income economies in Europe and North America, the estimates of earnings persistence for Germany, the UK, France, and the USA were above 40 percent. Income persistence in Turkey was estimated at 30 percent, which is below the average in Europe and Central Asia, and much lower than in its emerging market peers, such as Brazil and South Africa, with income persistence of above 60 percent. ${ }^{32}$ In Asia, where the average IGE is around 50 percent, studies of Taiwan and Singapore suggest very high-income mobility in these two countries - 18 and 26 percent, respectively.

Figure 11. Intergenerational Mobility in Income

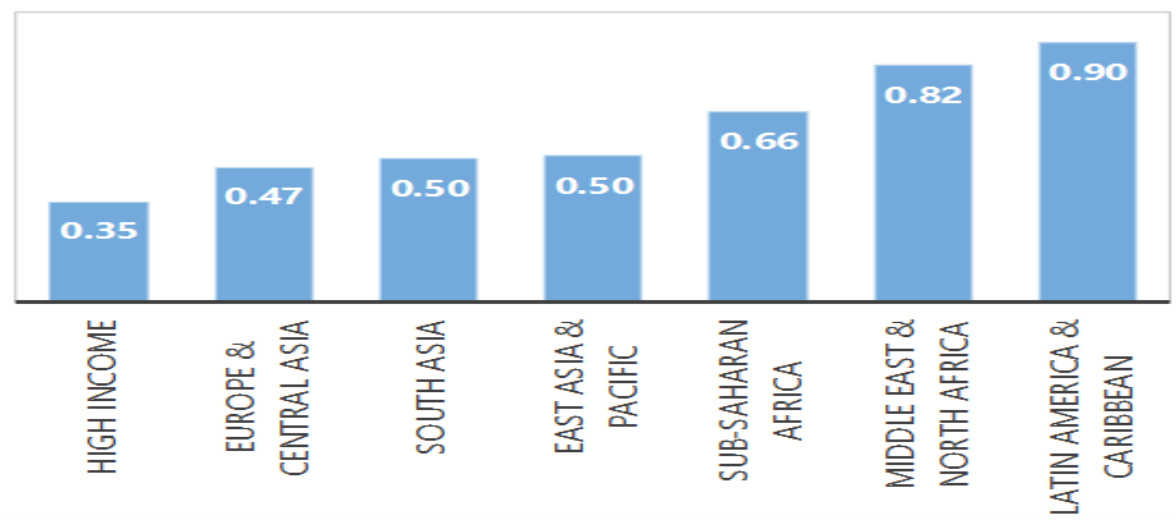

Source: GDIM. 2018. Global Database on Intergenerational Mobility. Development Research Group, World Bank.

Note: The graph shows estimates of persistence in income as measured by intergenerational income elasticity from the World Bank GDIM.

Intergenerational education mobility has a strong association with intergenerational persistence in wages. A World Bank's study estimates a range between 53 and 84 percent across the world, with the lowest education mobility in Sub-Saharan Africa and South Asia, and highest in Western Europe, Canada, Australia, and Japan (Figure 12). ${ }^{33}$ This measure is a coefficient from the regression of children's years of education on the education of their parents. $^{34}$

As in the case with income mobility, there is significant variation within regions. For example, in Africa, intergenerational mobility in education exceeded 70 percent in South

\footnotetext{
${ }^{31}$ OECD, 2018.

${ }^{32}$ GDIM. 2018. Global Da tabase on Intergenerational Mobility. Development Research Group, World Bank. Washington, D.C.: World Bank Group.

${ }^{33}$ World Bank, 2018.

${ }^{34}$ GDIM. 2018. Global Da tabase on Intergenerational Mobility. Development Research Group, World Bank. Washington, D.C.: World Bank Group.
} 
Africa and Botswana and was below 20 percent in Sudan, Mozambique, Burkina Faso, and Malawi. ${ }^{35}$ There is generally a positive correlation between mobility in earnings and education, but some notable exceptions exist.

\section{Figure 12. Intergenerational Mobility in Education}

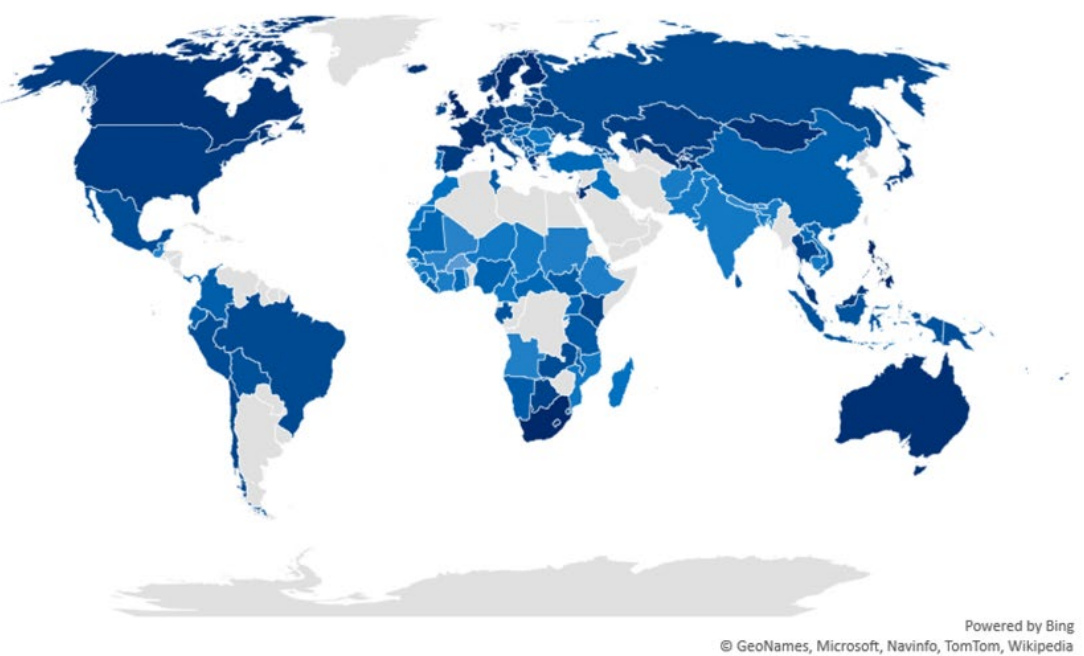

Source: Narayan, Ambar; Van der Weide, Roy; Cojocaru, Alexandru; Lakner, Christoph; Redaelli, Silvia; Mahler, Daniel Gerszon; Ramasubbaiah, Rakesh Gupta N.; Thewissen, Stefan. 2018. Fair Progress? Economic Mobility Across Generations Around the World. Equity and Development. Washington, DC: World Bank.

Note: darker shades indicate higher intergenerational education mobility; gray color indicates that data is unavailable.

\section{Social mobility in occupational status reflects social inequalities and has an impact on} individuals' life chances and life choices. There are several ways to study social mobility based on occupation or social class. Relative social mobility in the occupation can be defined as the probability that a child born to parents from a particular social class remains in this social class. In their analysis for presentational purposes, the OECD ${ }^{36}$ aggregates social classes based on occupation into three broad categories: manual workers, routine workers, and managers. Their findings show that about a third of children from manual workers remain manual workers themselves, while half of the children with parents in managerial class become managers. As job structure changes and new forms of employment emerge, there may be a need for new measures of social mobility.

\section{Prospects of social mobility can vary within a country, where the chances of being} successful are linked to where a person lives. Chetty et al. (2014) establish that there is substantial variation in intergenerational mobility across different areas in the US. ${ }^{37}$ In the UK, according to the Social Mobility Commission, the population living in London and the commuter belt areas around it are more socially mobile in comparison to the rest of the country. In these areas, children, including those from disadvantaged backgrounds,

\footnotetext{
${ }^{35}$ Alesina, A., et al., 2019.

${ }^{36}$ OECD, 2018.

${ }^{37}$ Chetty R., et al., 2014.
} 
demonstrate excellent results at school and have better higher education opportunities. In contrast, young people from some of the isolated rural and coastal towns have poorer chances of achieving good educational outcomes and lack access to further education and employment opportunities. ${ }^{38}$ Alesina et al. (2019) show that proximity to the coast and the capital city in Africa within a country leads to higher mobility, even after conditioning on the initial level of literacy. They also find that malaria-prone regions tend to have lower social mobility. 39

Studies suggest some differences in social mobility between women and men. Women are more likely than men to achieve a higher level of education than that of their parents. OECD finds that there is a gender gap in upward educational mobility in favor of women, which is particularly wide in Denmark, Estonia, Finland, and Italy. ${ }^{40}$ At the same time, the mobility of educational attainments between mothers and daughters tends to be lower than the mobility between fathers and sons. OECD finds such patterns in southern Europe and the emerging market economies. ${ }^{41}$ Some studies suggest women tend to have greater occupational mobility than men. ${ }^{42}$ However, occupational segregation by gender remains a barrier to many women. Relative earnings mobility tends to be similar for daughters and sons. ${ }^{43}$ Although certain patterns of social mobility for women and men emerge, the estimates are likely to be country-specific, and as we suggested earlier, can also vary within countries.

\section{B. Barriers and drivers of social mobility}

People can face barriers to social mobility at different stages of their life. At the early stage, early childhood education and care give children a good start in life. Certain features of the secondary and tertiary education system can create obstacles for upward social mobility. For example, early selection and tracking can explain limited educational mobility in some of the EU member states. ${ }^{44}$ The transition from school to employment poses challenges related to youth unemployment and may leave a large number of youth among those who are not in employment, education, or training (NEET). Lack of access to certain occupations is linked to the parental background, and in some instances, to discrimination, elitism, and nepotism. Especially affected are women and ethnic minority groups. Various shocks related to health, changes in marital and job status in the absence of effective social protection mechanisms may damage the life prospects of the most vulnerable.

The Global Social Mobility Report by the World Economic Forum identifies main drivers of social mobility as policies, practices, and institutions across the following dimensions: health, education, technology, work, and social protection, and inclusive institutions. ${ }^{45}$ On a global

\footnotetext{
${ }^{38}$ State of the Nation 2017: Social Mobility in Great Britain.

${ }^{39}$ Alesina, A., et a l., 2019.

${ }^{40}$ OECD, 2017

${ }^{41}$ OECD, 2018.

${ }^{42}$ ILO, 2018 a.

${ }^{43}$ OECD, 2018.

${ }^{44}$ Eurofound, 2017.

${ }^{45}$ World Economic Forum, 2020, The Global Social Mobility Report.
} 
level, the report suggests that such areas as fair wage distribution and deficiencies in social protection coverage are challenges among several countries, while the lack of opportunities for lifelong learning are challenges faced by all countries analyzed in the report. Looking at findings across regions can offer several insights. While countries in North America are doing relatively well in such areas as access to technology, education quality, and health, as well as work opportunities and inclusive institutions, they could improve in such areas as high incidence of low wages, working conditions, and social protection that could help protect workers from adverse personal shocks. In Sub-Sharan Africa, countries could improve in several areas, including access and quality of education, fair wage distribution, and social protection.

\section{Policies to promote intergenerational mobility}

\section{Policies can have an impact on how advantages or disadvantages are transmitted from} parents to children. Such policies may include a wide range of measures, including policies to support health and education mobility, policies to support families, labor market policies, tax and transfer policies, local and urban development and planning and housing policies, access to technology, and, more broadly, policies and reforms aimed at building more inclusive institutions.

Policy interventions starting from one's early childhood to their transition to the labor market can bring positive returns in supporting social mobility. The phenomenon of sticky floors tends to emerge from a very early age and matter for opportunities later in life. Young people, in particular, those from disadvantaged backgrounds, may struggle at school, drop out from formal education, and encounter difficulties in the labor market. Policy options outlined in the section on "Your Poverty and Unemployment" provide an overview of measures that can help support families and youth and promote social mobility, including the need to provide life-learning opportunities and effective social protection schemes. Moreover, policies should also emphasize the need to tackle various types of discrimination in the labor market. Such measures can facilitate job access to professions based on candidates' ability rather than their socioeconomic background or social network.

Policies to support working parents can also be instrumental. Such policies can focus both on providing flexible working hours to parents, financial support for childcare as well as providing support in developing parental skills. For example, the Parenting Early Intervention Program (PEIP) in the UK focuses on parents from socially disadvantaged backgrounds emphasizing the role of such skills. ${ }^{46}$ Promotion of access to childcare for ethnic minorities is another measure to promote social mobility.

Social mobility also requires policies to reduce spatial segregation and inequalities between neighborhoods in cities. Measures to improve access to good-quality education, health, jobs, and affordable housing as well as the development of transport infrastructure on

\footnotetext{
${ }^{46}$ Think Family Toolkit, Guidance note 07, 2010, https://dera.ioe.ac.uk/9475/17/Think-Family07.pdf
} 
a local level, have been recommended as policies to address regional or spatial divide within countries. Measures to improve access to jobs and to create job opportunities at the local level may include tax breaks and creating enterprise zones as employment support programs. Such measures may need to be considered carefully not to undermine the tax base and thus make it difficult to support the needed public infrastructure.

Tax policies that affect wealth accumulation can also affect social mobility. Wealth is more unequally distributed than income, and wealth deprivation can cause "sticky floors", while wealthier parents are likely to pass on their advantage to their children ("sticky ceilings").

In short, social mobility and social inequalities are not set in stone. Policies can help in promoting equality of opportunity to avoid passing the socioeconomic disadvantages from one generation to another. 


\section{CONCLUSIONS}

Sharing economic benefits equitably across all segments of society includes addressing the specific challenges of different generations. The youth, who are trying to establish themselves in the labor market, and the elderly, who in some countries have limited incomes after completing their working lives, are typically more vulnerable to poverty relative to adults in their middle years.

Strategies to foster youth integration into the labor market need to be broad-based. They include good quality primary education all the way up to tertiary education, vocational training, and apprenticeships. Additional policies would include flexible labor markets with social safety nets to protect workers and active labor market policies from supporting employment along with measures to foster private sector development and entrepreneurship.

The elderly often rely on income and health care support from public systems that are under increasing strains due to demographic and other trends. In countries with comprehensive and mature systems of social protection and aging populations, policies should maintain a good balance between financial sustainability and pension adequacy. In many developing countries with large informal sectors, the policy objective is to broaden coverage and increase formalization.

There might not be a general consensus on the desirable level of inequality of outcomes, but there is widespread agreement on the need to promote equality of opportunities. Everyone should have the same chances in life, regardless of their initial socioeconomic positions and that of their parents. In that sense, equality of opportunity is closely related to relative intergenerational mobility or social mobility. There is an increasing concern that social mobility has been declining, and this can have a negative impact on economic growth, affect life satisfaction and social cohesion. Policies that may help promote social mobility include early intervention such as supporting early childhood education and care, labor market policies to better integrate the young and improve access to certain jobs, measures to tackle spatial segregation and concentration of poverty and investment in housing and infrastructure. Effective social protection schemes can also provide safety against unexpected income losses, especially for those most vulnerable and in precarious employment. 


\section{REFERENCES}

Ahn, J. and others, 2019, "Improving youth labor market outcomes in emerging market and developing economies," IMF Staff Discussion Note 19/02.

Alesina, A, S Hohmann, S Michalopoulos and E Papaioannou, 2019, "Intergenerational mobility in Africa," CEPR Discussion Paper 13497.

Alesina, A., Stantcheva, S., and Teso, E., 2018, "Intergenerational Mobility and Preferences for Redistribution," American Economic Review, Vol. 108, No. 2, 521-554

Angel-Urdinola, D. and Semlali, 2010, "Labor Markets and School-to-Work Transition in Egypt: Diagnostics, Constraints, and Policy Framework,” World Bank, Washington DC.

Angel-Urdinola, D. and R. Leon-Serano, 2013, “A reform agenda for improving the delivery of ALMPs in the MENA region," IZA Journal of Labor Policy 2:13.

Assaad, R. and C. Krafft, 2016, "Labor Market Dynamics and Youth Unemployment in the Middle East and North Africa: Evidence from Egypt, Jordan and Tunisia," Working Paper 993, Economic Research Forum; Manacorda, M., and others (2017): "Pathways from school to work in the developing world," LSE Research Online.

Banerji, A. and others, 2014, "Youth Unemployment in Advanced Economies in Europe: Searching for Solutions,” IMF Staff Discussion Note, December 2014.

Barro, R. J., 2001, Human capital and growth. American Economic Review, 91(2), 12-17.

Benartzi, Shlomo, and RichardThaler, 2013, "Behavioral Economics and the Retirement Savings Crisis," Science, Vol. 339, No. 6124

Breen, R., 2019, "Education and Intergenerational Social Mobility in the US and four European countries.” Oxford Review of Economic Policy, Vol. 35, No 3, pp. 445-466.

Chetty, R., Hendren, N, Kline, P., Saez, E., 2014, "Where is the land of opportunity? The Geography of Intergenerational Mobility in the US, NBER Working Paper 19843.

Cho, Y. and others,2012, "Labor Markets in Low- and Middle-Income Countries: Trends and Implications for Social Protection and Labor Policies," Social Protection and Labor Discussion Paper 1207, World Bank Group.

Dibeh and others (2016): "The poor and marginalized in Lebanon: Labor market challenges and policy implications," SAHWA Policy Paper, 1, CIDOB - Barcelona; World Bank.

Dimova, R., S Elfer, and K. Stephan, 2016, "Labour market transitions of young women and men in the Middle East and North Africa," Work4 Youth Publication Series 44, ILO.

Duval, R. and P. Loungani, 2019, "Designing Labor Market Institutions in Emerging and Developing Economies: Evidence and Policy Options," IMF Staff Discussion Note $19 / 04$. 
Elborgh-Woytek, K. and others, 2013, "Women, Work, and the Economy: Macroeconomic Gain from Gender Equity," Staff Discussion Note 13/10, International Monetary Fund.

Erikson, R., Goldthorpe, J., Portocarero, L., 1979, “Intergenerational Class Mobility in Three Western European Societies: England, France, and Sweden," The British Journal of Sociology, Vol. 30, No. 4, pp. 415-441.

Eurofound, 2017, Social mobility in the EU, Publications Office of the European Union, Luxembourg https://www.eurofound.europa.eu/sites/default/files/ef publication/field ef document/ef 1664en.pdf

European Bank for Reconstruction and Development, 2016, Transition Report 2016-17.

European Commission, 2012, The 2012 Ageing Report: Economic and Budgetary Projections for the 27 EU Member States (Brussels: Directorate-General for Economic and Financial Affairs, European Commission).

Evans, B. and Palacios, P., 2015. "Who is Poorer? Poverty by Age in the Developing World".

Figliuoli, Lorenzo U et al. "Growing Pains; Is Latin America Prepared for Population Aging?", IMF Departmental Paper, 2018.

Filmer, Deon and Louise Fox, 2014, "Youth Employment in Sub-Saharan Africa. Africa Development Series. Washington, DC: World Bank.

Fox, L., and U. Kaul, 2017, "How Should Youth Employment Programs in Low-Income Countries be Designed?" Policy Research Working Paper 8500, World Bank Group.

GDIM. 2018. Global Database on Intergenerational Mobility. Development Research Group, World Bank. Washington, DC: World Bank Group.

Gonzales, C. and others, 2015, "Fair play: more equal laws boost female labor force participation," IMF Staff Discussion Note.

Hanushek, E. A., \& Woessmann, L., 2012, “Do better schools lead to more growth? Cognitive skills, economic outcomes, and causation.", Journal of Economic Growth, 17(4), 267-321.

Hassan and Sassanpoor, 2008, "Labor market pressures in Egypt: why is the unemployment rate stubbornly high?"

Hawkins, J., 2019, “The rise of young adult poverty in the US," Issue Brief.

ILO (International Labour Office), 2017. World Social Protection Report 17-19.

International Labor Organization, 2018, “Intergenerational Mobility: A Dream Deferred?"

Research Paper, ILO Future of Work Research Paper Series.

https://www.ilo.org/wcmsp5/groups/public/---dgreports/---

cabinet/documents/publication/wcms 649496.pdf 
International Labor Organization, 2018a, “Intergenerational Mobility: A Dream Deferred?" Research Paper, ILO Future of Work Research Paper Series https:/www.ilo.org/wcmsp5/groups/public/---dgreports/--cabinet/documents/publication/wcms 649496.pdf

International Labour Organization, 2011, "Increasing the employability of disadvantaged youth," Skills for Employment Policy Brief Series, ILO.

International Labour Organization, 2018b, "World Employment and Social Outlook - Trends 2018 ", ILO.

International Labour Organization, 2020a, "World Employment and Social Outlook - Trends 2020", ILO.

International Labour Organization, 2020b, "Global Employment Trends for Youth 2020: Technology and the Future of Jobs", ILO.

Kakwani, Nanak, and Kalanidhi Subbarao, 2005. "Ageing and poverty in Africa and the role of social pensions," Working Papers 8, International Policy Centre for Inclusive Growth.

Kim, Seong Sook, 2014, Providing Adequate Old-Age Pensions in the Republic of Korea, in Benedict Clements, Frank Eich, and Sanjeev Gupta," Equitable and Sustainable Pensions. Challenges and Experience", International Monetary Fund.

Korea Development Institute, 2014, "Social Mobility: Experiences and Lessons from Asia," edited by Taejong Kim and Anthea Mulakala https://asiafoundation.org/wpcontent/uploads/2016/06/KDI-TAF-2014Social-Mobility-Experiences-and-Lessonsfrom-Asia.pdf

Krafft and Assaad, 2015, "Inequality of opportunity in the labor market for higher education graduates in Egypt and Jordan," ERF Working Paper 932, August.

Levy-Yeyati, E. M Montané and L Sartorio, 2019, "What Works for Active Labor Market Policies?”, Harvard University Center for International Development Faculty Working Paper No. 358

Manacorda, M., Rosati, F., Ranzani, M., \& Dachille, G., 2017, "Pathways from school to work in the developing world." LSE Research Online.

Matsumoto, M. and S. Elder, 2010, "Characterizing the school-to-work transition of young men and women: Evidence from the ILO school-to-work surveys," Employment Working Paper 51, ILO.

Narayan, Ambar; Van der Weide, Roy; Cojocaru, Alexandru; Lakner, Christoph; Redaelli, Silvia; Mahler, Daniel Gerszon; Ramasubbaiah, Rakesh Gupta N.; Thewissen, Stefan. 2018. Fair Progress? Economic Mobility Across Generations Around the World. Equity and Development. Washington, DC: World Bank. https://openknowledge.worldbank.org/handle/10986/28428 License: CC BY 3.0 IGO. 
Norges Bank Investment Management, 2020, Retrieved from https://www.nbim.no/ on April $17,2020$.

O’Higgins, N., 2017, "Rising to the youth employment challenge: New evidence on key policy issues," ILO.

OECD, 2017, “The Pursuit of Gender Equality: An Uphill Battle,” OECD Publishing, Paris. http://dx.doi.org/10.1787/9789264281318-en

OECD, 2018, “A Broken Social Elevator? How to Promote Social Mobility,” OECD Publishing, Paris. http://dx.doi.org/10.1787/9789264301085-en

OECD, 2019, Pensions at a Glance 2019: OECD and G20 Indicators, OECD Publishing, Paris.

OECD/ILO, 2019, "Women at Work: Progress and Policy Action," Paper prepared under Japan's G20 Presidency.

Palmer, R., 2008, "Skills and productivity in the informal economy"; Employment working paper 5, ILO.

Pew Research Center, 2015, "Family Support in Graying Societies: How Americans, Germans, and Italians Are Coping with an Aging Population."

Purfield, C. Finger, H., Ongley, K., Baduel, B., Castellanos, C., Pierre, G., Stepanyan, V., and E. Roos, 2018, "Opportunity for all: promoting growth and inclusiveness in the Middle East and North Africa," IMF Departmental Paper, Middle East and Central Asia Department.

Quintini, G. and S. Martin, 2014, "Same Same but Different: School-to-work Transitions in Emerging and Advanced Economies," OECD Social, Employment and Migration Working Papers, No. 154, OECD.

Shang, Baoping, 2014, "Pension Reform and Equity: The Impact on Poverty of Reducing Pension Benefits" in Benedict Clements, Frank Eich, and Sanjeev Gupta," Equitable and Sustainable Pensions. Challenges and Experience," International Monetary Fund.

Shehu, E. and Nilsson, 2014, "Informal Employment Among Youth: Evidence from 20 School-to-Work Transition Surveys,” International Labour Organisation, Geneva.

Sieverding, M., 2012, "Female disadvantage in the Egyptian labor market; a youth perspective," SYPE Policy Brief 4, The Population Council.

Social Mobility Barometer, 2018, "Public attitudes to social mobility in the UK," Social Mobility Commission https://assets.publishing.service.gov.uk/government/uploads/system/uploads/attachment data/file/766797/Social mobility barometer 2018 report.pdf

State of the Nation: Social Mobility in Great Britain, 2017, Social Mobility Commission, November 2017 
https://assets.publishing.service.gov.uk/government/uploads/system/uploads/attachment data/file/662744/State of the Nation 2017 - Social Mobility in Great Britain.pdf

Stiglitz, J., J. Fitoussi and M. Durand (eds.) (2018), For Good Measure: Advancing Research on Well-being Metrics Beyond GDP, OECD Publishing, Paris. https://doi.org/10.1787/9789264307278-enSun, F., Ueda, A., 2013, “Intergenerational earnings mobility in Taiwan," Economic Bulletin, Vol. 35, Issue 1, http://www.accessecon.com/Pubs/EB/2015/Volume35/EB-15-V35-I1-P21.pdf

Tamirisa, N. and others, 2018, "Title: Public wage bills in the Middle East and Central Asia," Departmental Paper, Middle East and Central Asia Department, International Monetary Fund, 2018.

The World Bank Global Database of Intergenerational Mobility (GDIM) https://www.worldbank.org/en/topic/poverty/brief/what-is-the-global-database-onintergenerational-mobility-gdim

Think Family Toolkit, Guidance note 07, 2010, https://dera.ioe.ac.uk/9475/17/ThinkFamily07.pdf

UK Parenting Early Intervention Programme, https://dera.ioe.ac.uk/9475/17/ThinkFamily07.pdf

United Nations Conference on Trade and Development (UNCTAD), 2017, "Robots, Industrialization, and Inclusive Growth," in "Trade and Development Report 2017: Beyond Austerity - Towards a Global New Deal", Chapter 3.

United Nations, 2019, World Population Prospects: the 2019 Revision

United Nations, 2020, Policy Brief: The Impact of COVID-19 on older persons. MAY 2020

United Nations, Department of Economic and Social Affairs, Population Division, 2017. World Population Ageing 2017 (ST/ESA/SER.A/408)

World Bank, 2012, "Enabling employment miracles," in "The Middle East and North Africa Region - A regional economic update," April 2012.

World Bank, 2014, "Jobs and privileges: unleashing the employment potential of the Middle East and North Africa," World Bank Regional Report.

World Bank, 2015. https://elibrary.worldbank.org/doi/pdf/10.1596/24992

World Bank, 2019. "World Development Report: The Changing Nature of Work."

World Economic Forum,2020, "The Global Social Mobility Report 2020", https://reports.weforum.org/social-mobility-report-2020/

World Health Organization, 2015, World Report on Aging and Health. World Health Organization. https://apps.who.int/iris/handle/10665/186463 
World Health Organization, 2020, “COVID-19 Strategy Update, April 14, 2020”. https://www.who.int/publications-detail/covid-19-strategy-update---14-april-2020

Zimmermann, K. and others, 2013, "Youth Unemployment and Vocational Training," Foundations and Trends in Microeconomics: Vol. 9: No. 1-2, pp 1-157.

Zouhar, Y., N. Lustig, J. Jellema, and M. Trabelsi, forthcoming, Public Expenditure and Inclusive Growth - A Survey. IMF Working paper. 